\title{
Characterization of natural and synthetic floating iron surface films and their associated waters
}

\author{
Perkins, R.B. ${ }^{a *}$, Gray, Z.N. ${ }^{\text {a }}$, Grathoff, G. ${ }^{\mathrm{b}}$, and Hugo, R. ${ }^{\mathrm{a}}$ \\ ${ }^{a}$ Department of Geology, Portland Sate University, 1721 SW Broadway, Portland, OR, 97201 \\ * Corresponding Author. e-mail: rperkins@pdx.edu tel: 503-725-3387 \\ ${ }^{b}$ Institute for Geography and Geology, Ernst-Moritz-Arndt Universität Greifswald, Friedrich- \\ Ludwig-Jahn-Str. 17A, D-17487 Greifswald Germany
}

\begin{abstract}
Naturally occurring floating iron surface films can be found in wetland and estuarine environments throughout the world, though they are often mistaken for oil sheens. While formation of biofilms at the sediment-water interface has been well documented, there has been surprisingly little mention of floating surface iron films in the geochemical literature, despite their ubiquitous nature. Two earlier studies determined that these films are amorphous or nanocrystalline, but disagree as to whether or not they contain mixed-valent iron and the importance of organic matter in their formation.

Here, we further characterize naturally occurring floating iron surface films in terms of their solid compositions and structure, as well as the aqueous environment in which they form. We then develop a methodology for synthesizing these films in order to examine how variations in key environmental conditions affect their formation and stability under controlled conditions. Our findings indicate that such films do contain mixed-valent iron and can form abiotically. We propose possible mechanisms for the formation and persistent occurrence of floating iron surface films. The first is essentially that humic acid coprecipitated with a ferric oxyhydroxide phase entraps and concentrates Fe(II) within diffusion limited microenvironments. The second is that of a cyclic transformation of initial ferrihydrite film to green rust via reduction by organic material followed by photo- / atmospheric-oxidation. Both processes may be important.
\end{abstract}

Key Words: iron (oxyhydr)oxide, surface films, wetlands, nanoparticles, organic complexation 


\section{Introduction}

Iron is an essential nutrient and plays a key role in the biogeochemical cycles of $\mathrm{N}, \mathrm{C}$, and S. The cycling of iron between particulate and dissolved species influences the fate of heavy metals, nutrients, and organic compounds through adsorption or coprecipitation and iron's active role in redox processes. The redox cycling of iron plays an important role in iron solubility and bioavailability, soil formation, and a variety of other environmental processes (Jickells et al., 2005; Poulton and Raiswell, 2002; Taylor and Konhauser, 2011). However, despite its obvious importance, there are still significant gaps in our understanding of iron geochemistry, especially those pertaining to poorly crystalline, mixed-valent iron oxides (Cornell and Schwertmann, 2003).

Naturally occurring floating iron surface films can be found in wetland and estuarine environments throughout the world. Because they are iridescent, these films are commonly mistaken for oil sheens. Unlike oil films, iron films break into distinct platelets when physically disturbed (Fig. 1). These films appear to be the earliest-forming solid phase during oxidation of dissolved ferrous iron and so play a critical role in iron cycling.

While formation of biofilms at the sediment-water interface has been well documented (Boult et al., 1997; Lear et al., 2009; Lo et al., 1996), there has been surprisingly little mention of floating surface iron films in the geochemical literature, despite their common occurrence in wetland environments. Grathoff et al. (2007) characterized such natural films collected from spring pools along the Oregon Coast, which they termed "schwimmeisen". They determined that the films were formed during oxidation of ferrous iron in groundwater discharging from dunal deposits, were amorphous or nano-crystalline, and contained mixed-valent iron with a nominal molar ratio of 1:3 Fe(II):Fe(III). Kleja et al. (2012) sampled floating films and iron precipitates 
from four sites (two groundwater seeps, a pond and a brook) in south-central Sweden. They analyzed floating surface films and precipitates collected from bottom sediments and a leaf via X-ray absorption spectroscopy (EXAFS and XANES) at the Lund University synchrotron facility along with a suite of iron reference phases. They determined that the samples from the groundwater seeps were predominantly ferrihydrite while samples from the pond and brook appeared to be mixtures of "iron (hydr) oxide (likely ferrihydrite)" and iron complexes with natural organic matter. Contrary to Grathoff et al. (2007), they found no evidence for the presence of $\mathrm{Fe}(\mathrm{II})$ in the films, but conceded that the samples were handled in an open atmosphere between sampling and analyses and that any Fe(II) phases present may have been oxidized.

Here, we further characterize naturally occurring floating iron surface films, including their solid compositions (including Fe valence) and structure, and the aqueous environment and chemistry in which they form. We then develop a methodology for synthesizing these films in order to examine how variations in key environmental conditions affect their formation and stability under controlled conditions, and provide an estimate of iron film solubility. Finally, we propose a model mechanism for the abiotic formation and persistent occurrence of iron surface films. 


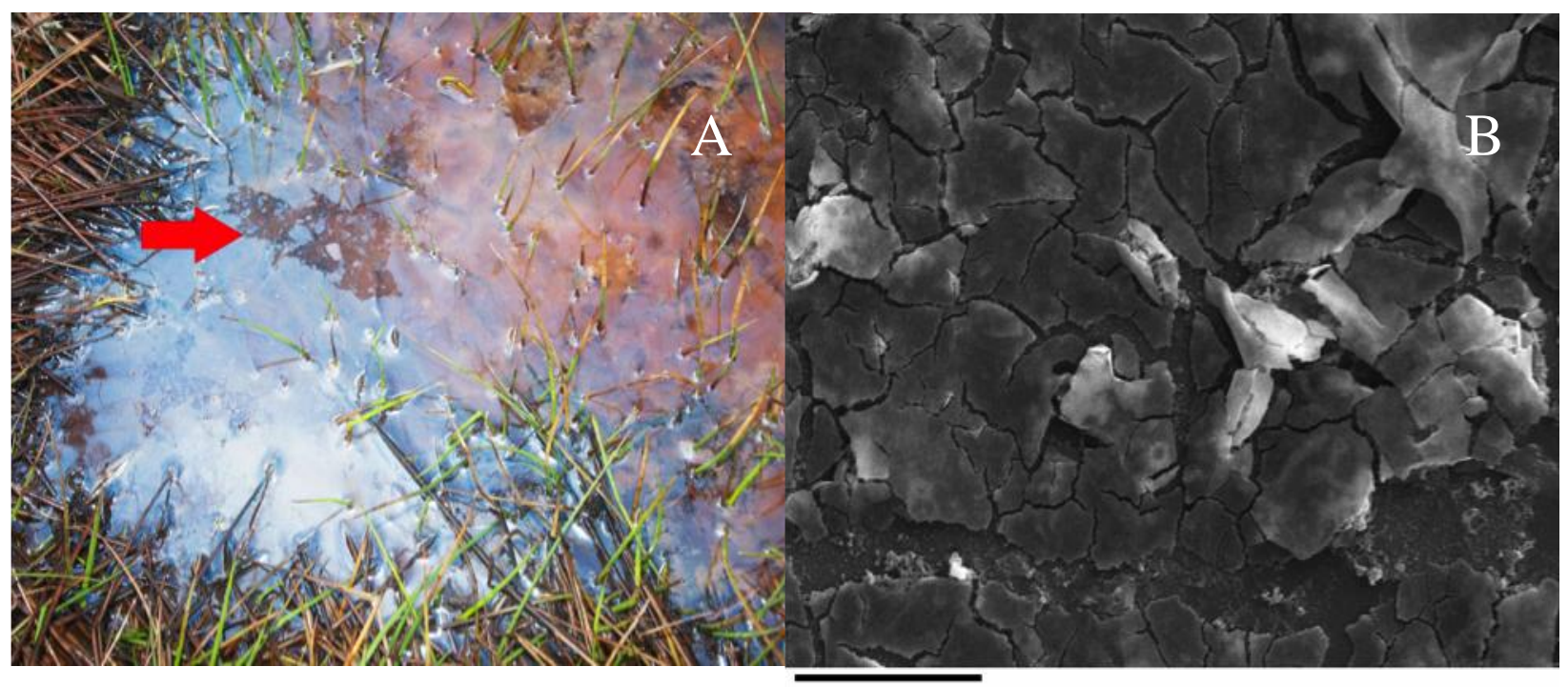

$10 \mu \mathrm{m} 3200 \mathrm{X}$

Figure 1. a) Image of floating iron film on a spring pool along central Oregon coast; arrow points to area where film is broken into plates. Note the orange flocculent (ferrihydrite) underlying pool on the right, outflow side where the film is thinner. The flocculent mass contains filaments, likely Leptothrix sp., an Fe-oxidizing bacterium. b) SEM image of film collected from another spring showing overall lack of features except for desiccation cracking and some displacement and curling along edges.

\section{Methods}

\subsection{Collection of Natural Samples}

Water and floating iron film samples were collected from a variety of natural environments throughout northwestern Oregon, including seeps and spring pools along the Central Oregon coast, wetlands and riparian zones in the Willamette Valley, and spring pools in the Cascade Mountains (Table 1). The pools and seeps from which the films were collected ranged in area from $\sim 40$ to $5,000 \mathrm{~cm}^{2}$ and from $\sim 1$ - to $15-\mathrm{cm}$ deep. Multiple samples were collected from three sites (JB, NW26, and TC) on different days to account for variations in environmental conditions such as temperature and surface water flow that could impact $\mathrm{pH}$, redox and aqueous concentrations.

Table 1. Locations and descriptions of sample sites.

\begin{tabular}{|l|l|l|l|l|} 
Sample ID & Location Description & Site Description & Latitude & Longitude \\
\hline
\end{tabular}




\begin{tabular}{|c|c|c|c|c|}
\hline JB-1 \& JB-2 & $\begin{array}{c}\text { Jackson Bottom } \\
\text { Wetlands, Hillsboro, OR }\end{array}$ & $\begin{array}{l}\text { Reconstructed } \\
\text { Wetlands }\end{array}$ & 45.4925 & -122.9842 \\
\hline MF & $\begin{array}{c}\text { Multnomah Falls, } \\
\text { Columbia River Gorge }\end{array}$ & $\begin{array}{c}\text { Riparian pool on } \\
\text { slope of Cascade } \\
\text { Mts } \\
\end{array}$ & 45.5710 & -122.1160 \\
\hline MS & $\begin{array}{c}\text { Moonshadow City Park, } \\
\text { Portland, OR }\end{array}$ & Riparian wetlands & 45.4606 & -122.7470 \\
\hline $\begin{array}{l}\text { NW26a \& } \\
\text { NW26b }\end{array}$ & $\begin{array}{l}\text { Beach at Lincoln City, } \\
\text { OR }\end{array}$ & $\begin{array}{c}\text { Seep at base of } \\
\text { sand dunes }\end{array}$ & 44.9842 & -124.0143 \\
\hline $\mathrm{RE}$ & $\begin{array}{l}\text { Road's End State Park, } \\
\text { Lincoln City, OR }\end{array}$ & $\begin{array}{l}\text { Riparian pool } \\
\text { within dunal } \\
\text { deposits }\end{array}$ & 45.0087 & -124.0091 \\
\hline TC-1 \& TC-2 & $\begin{array}{c}\text { Tryon Creek State Park, } \\
\text { Portland, OR }\end{array}$ & $\begin{array}{l}\text { Seeps at base of } \\
\text { forested hillside }\end{array}$ & 45.4401 & -122.6814 \\
\hline WW & $\begin{array}{c}\text { Wildwood Recreation } \\
\text { Area, Mt Hood Village, } \\
\text { OR }\end{array}$ & $\begin{array}{c}\text { Forested wetland } \\
\text { on slope of } \\
\text { Cascade Mts } \\
\end{array}$ & 45.3483 & -121.9909 \\
\hline
\end{tabular}

Iron film samples were collected on a variety of substrates, including 3-mm Cu grids for transmission electron microscopy (TEM), glass slides, plastic slides, and aluminum stubs for scanning electron microscopy (SEM) and X-ray diffraction (XRD). Samples for iron speciation analysis were collected on glass and $0.2-\mu \mathrm{m}$ Versapor membrane filters which were immediately placed in $6 \mathrm{~mL}$ of $1: 1 \mathrm{HCl}$ in 15-mL plastic centrifuge tubes to prevent oxidation (To et al., 1999). Glass and plastic slide samples were stored in argon-filled centrifuge tubes for transport to minimize subsequent oxidation. Samples of flocculant were collected from the water-sediment interface on aluminum stubs from two locations.

Water samples associated with the floating iron films were collected from below the surface of seeps and pools with dedicated syringes, using the syringe plunger to draw in water under slight vacuum to avoid oxidation and immediately filtering through stacked $0.45-\mu \mathrm{m}$ and $0.1-\mu \mathrm{m}$ polysulfone syringe filters into acid-washed low-density polyethylene (LDPE) bottles. Sample bottles were filled to avoid any headspace. At each site, $60 \mathrm{~mL}$ of filtered water was preserved 
with $\mathrm{HCl}$ for iron speciation analysis, $60 \mathrm{~mL}$ was preserved with $\mathrm{HNO}_{3}$ to $\mathrm{pH}<2$ for cation analysis, and another $60 \mathrm{~mL}$ was kept at $4{ }^{\circ} \mathrm{C}$ for anion analysis. Field blanks and duplicates were collected daily. Water temperature, $\mathrm{pH}$, and conductivity measurements were measured in situ using a YSI multi-parameter water meter calibrated with commercial buffers and standards. Total alkalinity was also measured in the field by titration with $\mathrm{HSO}_{4}$ acid to $\sim 4.5 \mathrm{pH}$ (bromcresol breen-methyl red endpoint). At some locations, Eh readings were also taken with the platinum tip $\mathrm{Ag}-\mathrm{AgCl}$ probe calibrated with freshly prepared Zobell solution.

\subsection{Sample Analyses}

Samples of the film and flocculant were analyzed using a JEOL 35-C Scanning Electron Microscope equipped with a Kevex Energy Dispersive X-Ray Spectrometer (EDS). All images are of the underside of the film, because the films were collected by pressing the substrate down

onto the topside of the films. All samples were coated with a $125 \AA$-thick layer of Au/Pd using a Gatan Precision Model 682 Etching Coating System and analyzed by SEM at a $15 \mathrm{kV}$ accelerating voltage. Samples collected on plastic slides were used for quantitative EDS analysis with a dead time of 20 to $25 \%$ at an angle of 25 degrees.

Solid film samples collected on the $\mathrm{Cu}$ grids were analyzed with a FEI Tecnai F-20 field emission TEM at Portland State University using EDS, brightfield imaging, energy-filtered electron diffraction (EFED), and electron energy loss spectroscopy (EELS) for determination of local chemical composition, morphology, crystal structure, and Fe valence, respectively. Analyses were performed at 200kV. EDS analysis was performed in brightfield mode. Both EFED and EELS patterns were azimuthally integrated using the Image $\mathbf{J}$ software package (Rasband, 1997-2014). Each resulting x, y radial plot was modeled as a least-squares sum of multiple Voigt functions, similar to the method used by Garvie and Buseck (1998). Background 
intensities were modeled by a cubic spline function and subtracted from the total intensity curve. Peak locations and widths were not constrained to expected values, but rather were computed empirically with the Fityk software package (Wojdyr, 2010).

Iron speciation analyses of aqueous samples and film samples dissolved in 1:1 $\mathrm{HCl}$ were analyzed using the Ferrozine method described by To et al. (1999) and Viollier et al. (2000), with scanning performed on a Beckman Coulter DU 730 Spectrometer at a wavelength of 562 nm. Aqueous samples were analyzed for major cations using a Perkin-Elmer AAnalyst 300 Atomic Adsorption Spectrophotometer (AAS) and for major anions using a Dionex Model 2500 Ion Chromatograph (IC). Aqueous samples were also analyzed for silica content using the molybdate blue method (Fishman and Friedman, 1989), with samples scanned at a wavelength of $700 \mathrm{~nm}$ after a 30-minute reaction period. Dissolved organic carbon was analyzed using a Shimadzu TOC-VCSH high total organic carbon analyzer. Solution chemistries were entered into the software PHREEQC (Parkhurst and Appelo, 2013) to obtain ion activities, calculated Eh values, solution charge balances, and saturation indices.

\subsection{Synthesis of Floating Iron Film}

A series of 45 synthesis experiments was conducted to determine a suitable method for synthesis of floating iron films and for determining some limiting factors for their formation. All of the methods were modified from the Schwertmann and Cornell (2000) method for formation of green rust. Concentrations of major reagents and their order of addition were varied to observe the effect on film formation. All syntheses were performed using reagent- or analytical-grade reagents. All solutions were prepared with 18 megaohm-cm $(\mathrm{M} \Omega-\mathrm{cm})$ water produced with a Barnstead Nanopure II system; immediately prior to use, the water was purged with Ar or $\mathrm{N}_{2}$ for $\sim 20$ minutes to minimize dissolved $\mathrm{O}_{2}$ and $\mathrm{CO}_{2}$. Initial preparations were conducted in an 
anaerobic chamber under a $\mathrm{N}_{2}\left(+4 \% \mathrm{H}_{2}\right)$ atmosphere with humidity controlled by the use of Drierite $^{\mathrm{TM}}$ desiccant.

The initial synthesis method (experiments Syn $1-8)$, here referred to as the modified green rust method (MGR), simply involved oxidizing Fe(II)-rich waters under atmospheric conditions. Newly purchased ferrous sulfate heptahydrate $\left(\mathrm{FeSO}_{4} \cdot 7 \mathrm{H}_{2} \mathrm{O}\right.$; Fisher, certified ACS grade crystal) was dissolved in $500 \mathrm{~mL}$ of water to form a $\sim 0.08 \mathrm{M}$ solution. Initially the $\mathrm{pH}$ was ca. 3.5 at $24^{\circ} \mathrm{C}$. The solution $\mathrm{pH}$ was then buffered by titrating with $0.3 \mathrm{M} \mathrm{NaOH}$ prepared using Aldrich brand ACS grade reagent. After the addition of $\sim 1.5 \mathrm{~mL}$ of $\mathrm{NaOH}$ the solution took on a yellow tint and at $\sim 2.5 \mathrm{~mL}$ the solution was yellowish green. At a $\mathrm{pH}$ of $\sim 6.5$ a dark green precipitate (green rust) formed and no more $\mathrm{NaOH}$ was added. The solution was removed from the anaerobic chamber and left for 72 hours unstirred to allow atmospheric oxygen to begin oxidizing the solution from the asir-solution interface. Although this method produced floating materials that occupied $\sim 30-70 \%$ of the solution surface, the material visually appeared crystalline and quite unlike natural floating iron films.

The second synthesis method (UVB) entailed oxidizing a ferrous sulfate heptahydrate solution under a 7\% ultraviolet B (UVB) producing T-8 fluorescent lamp in an aneorobic chamber in which oxygen levels were maintained at or below $0.15 \%$. The solutions would have contained $80 \mathrm{mM} \mathrm{Fe}(\mathrm{II})$ if the ferrous salt was fully dissolved. This was not the case as considerable precipitate formed once the $\mathrm{pH}$ was elevated. To buffer $\mathrm{pH}$ in these synthesized solutions (Syn9 - 12), $2.0 \mathrm{~g}$ calcium carbonate was added to the beakers containing $400 \mathrm{~mL}$ of solution, yielding a $\mathrm{pH}$ between 6 and 7. This method produced floating material that also appeared more crystalline than natural films. Humic acid was added to the Syn 9 solution after it had been in the anaerobic chamber for 48 hours. The impact of this humic acid addition led to 
the final synthesis method described below.

The third method (Modified-UVB) employed the same procedure as the UVB method above, but with the addition of $8 \mathrm{ml}$ of a $0.2 \%$ solution of humic acid (Aldrich, $\mathrm{CP}$ grade) to the initial $400 \mathrm{ml}$ solution. Assuming a carbon content 50 to $60 \%$ (e.g., Giovanela et al., 2004), the resulting humic acid concentration $(\sim 40 \mathrm{mg} / \mathrm{L})$ equates to a DOC concentration of 20 to 24 $\mathrm{mg} / \mathrm{L}$, well within the range of DOC concentrations reported for natural waters $(\sim 1-34 \mathrm{mg} / \mathrm{L}$; Stronhmeier et al., 2013; Thurman, 1985). The prepared solutions (Syn 13-22) were initially prepared in the anaerobic chamber and then left there or placed in an aerobic environment under UVB light for up to 144 hours to observe the evolution of the films. This technique led to a film visually resembling natural floating iron films, covering $75-100 \%$ of the solution surface and with varying thicknesses as indicated by the degree of iridescence. Films formed under aerobic conditions tended to be thinner than films formed under anaerobic conditions.

An additional series of 20 experimental solutions (Syn 23-42) were prepared, systematically varying the concentrations of key components (Fe(II) and $\mathrm{Fe}(\mathrm{III})$ salts and $\mathrm{Si}$ ) to determine the range of solution chemistries that would yield films most similar to those found in natural environments and optimize the synthesis method (Table 2). The ratio of $\mathrm{Fe}(\mathrm{II})$ to $\mathrm{Fe}(\mathrm{III})$ was varied from $100 \% \mathrm{Fe}(\mathrm{II})$ to $1: 1$ to $100 \% \mathrm{Fe}$ (III) using $\mathrm{Fe}_{2}\left(\mathrm{SO}_{4}\right) 3 \cdot 5 \mathrm{H}_{2} \mathrm{O}$ (Alfa Aesar, $98+\%$ ) as the $\mathrm{Fe}(\mathrm{III})$ source and both $\mathrm{FeSO}_{4} \cdot 7 \mathrm{H}_{2} \mathrm{O}$ and $\mathrm{FeCl}_{2} \cdot 4 \mathrm{H}_{2} \mathrm{O}$ (Fisher, 99\%) as the $\mathrm{Fe}$ (II) to maintain sulfate and chloride concentrations close (within $1.5 \mathrm{x}$ ) to concentrations found in natural waters. The total amount of Fe added was $80 \mathrm{mM}$ (if dissolved), except for the $100 \% \mathrm{Fe}$ (III) solutions, where it was $40 \mathrm{mM}$. The amount of calcium carbonate and humic acid added was kept constant throughout as per the Modified-UVB method. Because Grathoff et al. (2007) concluded that silica was present in the films, silica was added (as $\mathrm{Na}_{2} \mathrm{SiO}_{3} \cdot 9 \mathrm{H}_{2} \mathrm{O}$; Aldrich, $98+\%$ ) at varying 
concentrations $(0,0.2,0.5$. and $2.0 \mathrm{mM})$ to determine its effect on film formation. Silica concentrations in waters associated with naturally occurring iron films ranged from 0.2 to 0.5 $\mathrm{mM}$. Because the addition of sodium metasilicate would otherwise raise the $\mathrm{pH}$ above 8 , dilute hydrochloric acid was also added to achieve ca. $6 \mathrm{pH}$ after all other reagents had been added. The order of addition of the reagents was also varied to determine if this had an affect on the products formed. In four of the five subgroups of solutions made, reagents were added in the order: iron, calcium carbonate, silica, humic acid, and $\mathrm{HCl}$. In the fifth group, the order of reagent addition was changed to humic acid, iron, calcium carbonate, silica, and $\mathrm{HCl}$. When $\mathrm{Fe}(\mathrm{II})$ and calcium carbonate were added first, a green rust precipitate formed in the solutions. Once the humic acid was added, the waters turned a tea color and the color of the precipitate could no longer be determined. Film, visually similar to natural films, formed on 13 of the 20 solutions. The duration of the final experiments conducted under anaerobic conditions was 25 days; select samples were left several weeks longer to see if the films continued to grow. The aerobic portion of the experiment (Syn39-42) lasted three days, as film had formed on the solutions in this amount of time. At a minimum (with two exceptions due to sample loss), $\mathrm{pH}$ and iron speciation analyses were performed on solutions from this set of 20 experiments.

Three final solutions ( $\mathrm{Syn} 43$-Syn 45) contained either $\mathrm{AgCl}_{2}, \mathrm{AgNO}_{3}$, or Aquicide TM Hydroblue water purifier to preclude bacterially-mediated film formation and to verify that the film would form abiotically. Silver was chosen because it is a widely used nonspecific antimicrobial that acts against a broad spectrum of microorganisms, as well as biofilms (Babu et al., 2006). Concentrations above $0.04 \mathrm{mg} / \mathrm{L}$ have been shown to retard microbial growth (Yahya et al., 1992). The concentrations used (1.1 mg/L silver chloride and $0.6 \mathrm{mg} / \mathrm{L}$ silver nitrate) were well above this concentration. Hydroblue was added at the amount the manufacturer's 
recommended for sterilization. Detailed results are discussed below.

Table 2. Experimental matrix for Modified-UVB synthesis experiments. Italicized numbers refer to synthesis solutions 23-42.

\begin{tabular}{|c|c|c|c|c|c|}
\hline \multirow[b]{2}{*}{ Environment } & \multirow{2}{*}{$\begin{array}{c}\text { Fe reagent type } \& \\
\text { amount }\end{array}$} & \multicolumn{4}{|c|}{ Amount of silica } \\
\hline & & $0.0 \mathrm{mM}$ Si & $0.2 \mathrm{mM} \mathrm{Si}$ & $0.5 \mathrm{mM}$ Si & $2.0 \mathrm{mM} \mathrm{Si}$ \\
\hline \multirow[t]{3}{*}{ Anaerobic } & $0.04 \mathrm{M} \mathrm{Fe}$ (III) & 31 & 32 & 33 & 34 \\
\hline & $\begin{array}{l}0.04 \mathrm{M} \mathrm{Fe}(\mathrm{II}) / 0.04 \mathrm{M} \\
\mathrm{Fe}(\mathrm{III})\end{array}$ & 27 & 29 & 28 & 30 \\
\hline & $\begin{array}{l}0.08 \mathrm{M} \mathrm{Fe}(\mathrm{II}) \\
0.08 \mathrm{M} \mathrm{Fe}(\mathrm{II}) / \\
\text { Alternate Reagent } \\
\text { Order }^{1}\end{array}$ & 23 & 24 & $37 *$ & 26 \\
\hline
\end{tabular}

\begin{tabular}{llllll} 
Aerobic & $0.08 \mathrm{M} \mathrm{Fe}(\mathrm{II})$ & 39 & 40 & 41 & 42 \\
\hline \hline
\end{tabular}

${ }^{1}$ : Order in which reagents were added altered from iron salt(s), calcium carbonate, silica, humic acid, and $\mathrm{HCl}$ to: humic acid, iron salt(s), calcium carbonate, silica, and $\mathrm{HCl}$.

*: Indicates experiment repeated three times with addition of $\mathrm{AgCl}_{2}, \mathrm{AgNO}_{3}$, or Aquicide ${ }^{\mathrm{TM}}$ Hydroblue microbicides.

\section{Results}

\subsection{Chemistry of Associated Waters}

Field parameters, including temperature, $\mathrm{pH}$, Eh, and alkalinity are listed in Table 3 and ion concentrations are provided in Table 4. Speciated charge balance errors (CBEs) for eight of eleven samples ranged from -6.3 to $+0.9 \%$, averaging $-2.6 \%$; CBEs for three other samples could not be determined as alkalinity was not measured, but estimated based on charge balance. The 
$\mathrm{pH}$ values of natural waters where film was present ranged from 5.93 to 6.97. These values are typical of surface and shallow groundwaters in western Oregon, though considerably less than Kleja et al. (2012) measured in three of the four film-associated water samples they collected in south-central Sweden $(7.6-8.1 \mathrm{pH})$. Total iron concentrations in natural waters where film was present range from 1.3 to $23 \mathrm{mg} / \mathrm{L}$, with an average value of $8.1 \mathrm{mg} / \mathrm{L}$. The predominant form of 'dissolved' $(<0.1 \mu \mathrm{m})$ iron in aqueous samples is $\mathrm{Fe}(\mathrm{II})(0.53$ to $19.8 \mathrm{mg} / \mathrm{L})$, though there is a considerable amount of Fe(III) present in each sample (up to $6.4 \mathrm{mg} / \mathrm{L}$, averaging $1.7 \mathrm{mg} / \mathrm{L}$ ). $\mathrm{Fe}(\mathrm{III})$ appeared to be the predominant form of iron in two samples, WW and MS2, but the CBE for both samples is $>+14 \%$, suggesting possible issues with filtration. Colloidal particles range in size from $1 \mathrm{~nm}$ to $100 \mu \mathrm{m}$, such that the smallest fractions of colloidal ferric oxyhydroxide would not be filtered out by a $0.1 \mu \mathrm{m}(100 \mathrm{~nm})$ filter, making it appear as though there is a concentration of 'dissolved' ferric iron. Cornell and Schwertmann (2003) state that ferrihydrite's primary particle diameter size is $5 \mathrm{~nm}$, making filtration through any conventional filter an impossibility for removing all colloidal iron, which could explain the high 'dissolved' Fe(III) concentrations. The range of field-measured Eh values $(250-354 \mathrm{mV})$ generally agree with values calculated with PhreeqC from Fe(II):Fe(III) concentrations (average difference = 38 mv; Table 2), although four of five values are larger than calculated.

As expected, the concentrations of chloride and sodium are highest in samples collected along the Oregon coast, with values as high as 1200 and $1600 \mathrm{uM}$, respectively. Measured concentrations of DOC in natural waters $(n=11)$ range from 100 to $2100 \mathrm{uM}$, averaging $460 \mathrm{uM}$; the highest concentration was measured in a sample collected from a managed wetland used for tertiary sewage treatment.

Table 3. Field-measured parameters and calculated Eh for associated waters.

\begin{tabular}{l||ccccc}
\hline \hline Sample ID & Temp (C) & pH & Meas. Eh & Calc. Eh & Alkalinity \\
\hline \hline
\end{tabular}




\begin{tabular}{r||ccccc}
\hline \hline & & & $(\mathbf{m V})$ & $\mathbf{( m V})$ & $\mathbf{( m q / L} \mathbf{~ a s ~ C a C O})$ \\
\hline \hline JB-1 & 21.8 & 6.52 & $\mathrm{~nm}$ & 312 & 88 \\
JB-2 & 12.8 & 6.30 & 274 & 352 & 56 \\
MF & 14.5 & 6.97 & $\mathrm{~nm}$ & 256 & 28 \\
MS-1 & 9.9 & 6.88 & 250 & 285 & 63 \\
MS-2 & 15.0 & 6.51 & 269 & 386 & 34 \\
NW26a & 12.0 & 6.36 & $\mathrm{~nm}$ & 279 & 21 \\
NW26b & 12.6 & 6.57 & $\mathrm{~nm}$ & 318 & 17 \\
RE & 9.3 & 6.55 & $\mathrm{~nm}$ & 261 & 59 \\
TC-1 & 5.7 & 6.40 & 338 & 356 & 35 \\
TC-2 & 4.4 & 6.74 & 354 & 240 & 39 \\
WW & 15 & 6.55 & $\mathrm{~nm}$ & 357 & 25 \\
\hline \hline
\end{tabular}

Ehs calculated using Visual Minteq and Stockholm Humic Model (Active DOM =60\% fulvic acid)

nm: Not measured; Italicized alkalinity values estimated from charge balance.

Table 4. Major ion and DOC concentrations (uM) and calculated charge balance errors for associated waters. Fe(II) and (III) ratios of associated films are provided in the last column.

\begin{tabular}{|c|c|c|c|c|c|c|c|c|c|c|c|c|c|c|}
\hline $\begin{array}{c}\text { Sample } \\
\text { ID } \\
\end{array}$ & $\mathbf{C a}$ & Mg & $\mathrm{Na}$ & $\mathbf{K}$ & $\mathbf{F e}^{(\mathrm{II})}$ & $\mathbf{F e}^{(\mathrm{III})}$ & $\mathrm{Cl}$ & $\mathrm{SO}_{4}$ & $\mathbf{F}$ & $\mathrm{NO}_{3}$ & $\mathrm{SiO}_{2}$ & DOC & $\begin{array}{c}\text { CBE } \\
(\%) \\
\end{array}$ & $\begin{array}{c}\text { Solid Film } \\
\text { Fe(II):Fe(III) }\end{array}$ \\
\hline JB-1 & 188 & 344 & "438 & 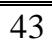 & 153 & 48 & "64 & 8.1 & "6.3 & 3.1 & 189 & 2181 & $\begin{array}{l}-- \\
\end{array}$ & 0.18 \\
\hline JB-2 & 63 & 173 & 491 & 26 & 226 & 40 & 329 & 8.0 & 4.2 & 10 & 270 & -- & -- & 0.17 \\
\hline $\mathrm{MF}$ & 91 & 147 & 375 & 21 & 22 & 3.4 & 320 & 3.0 & 2.6 & 15 & 142 & 275 & -3.2 & 0.22 \\
\hline MS-1 & 156 & 231 & 364 & 48 & 341 & 70 & 166 & 74 & 6.8 & 78 & 301 & 351 & 6.8 & 0.027 \\
\hline MS-2 & 104 & 136 & 332 & 38 & 32 & 110 & 310 & 73 & 7.4 & 53 & 159 & 511 & -9.7 & 0.05 \\
\hline NW26-1 & 70 & 202 & 1010 & 42 & 80 & 3.7 & 1200 & 61 & 0.9 & 6.3 & 237 & 110 & -0.68 & 0.12 \\
\hline NW26-2 & 79 & 213 & 1000 & 41 & 28 & 8.4 & 1220 & 58 & 1.6 & 16 & 341 & 96 & 0.16 & 0.23 \\
\hline $\mathrm{RE}$ & 85 & 186 & 1270 & 48 & 355 & 12 & 1600 & 33 & 0.5 & 17 & 112 & 257 & -1.8 & 0.16 \\
\hline TC-1 & 81 & 330 & 275 & 35 & 65 & 27 & 97 & 100 & 7.9 & -- & 523 & 284 & 7.9 & 0.18 \\
\hline TC-2 & 78 & 317 & 321 & 35 & 35 & 7.8 & 122 & 101 & 9.5 & 44 & 366 & 390 & 1.5 & 0.03 \\
\hline WW & 69 & 89 & 163 & 30 & 9 & 15 & 57 & 14 & 2.1 & 4.0 & 213 & 120 & -4.3 & 0.14 \\
\hline
\end{tabular}

Speciated charge balance errors calculated with Visual Minteq using Stockholm Humic Model. "--“": alkalinity was determined via charge balance.

Solid film iron ratios determined by colorimetric analyses of $1: 1 \mathrm{HCl}$ solutions in which films were dissolved (after To et al., 1999). Italicized (lowest) values are for samples collected from very small inland wetland pools which likely had no continuous groundwater inflow.

\subsection{Analyses of Naturally Occurring Floating Iron Films}

All natural film samples display similar macroscopic characteristics, exhibiting iridescence 
and breaking into platelets when disturbed (Fig. 1a). SEM imaging reveals films to be platey, with little surface topography other than cracking associated with dehydration of the films (Fig 1b). Additional material such as flocculant or organic material was observed attached to the film in all samples, though such material was scattered and occupied only a relatively small percentage of total surface area, similar to that reported by Grathoff et al. (2007).

Chemical analyses of 11 naturally occurring iron films dissolved in 1:1 $\mathrm{HCl}$ yielded a mean $\mathrm{Fe}(\mathrm{II}): \mathrm{Fe}(\mathrm{III})$ ratio of 0.14 and a median ratio 0.16 , with values ranging from 0.02 to 0.23 . Chemical analyses of 11 naturally occurring iron films dissolved in 1:1 $\mathrm{HCl}$ yielded a mean $\mathrm{Fe}(\mathrm{II}): \mathrm{Fe}(\mathrm{III})$ ratio of 0.14 and a median ratio 0.16 , with values ranging from 0.02 to 0.23 . Three of the samples, MS-1, MS-2, and TC-2, were collected from very small pools filled by intermittent surface or ground water flow, and essentially stagnant at the time of collection. These are the only three samples with Fe(II):Fe(III) ratios <0.1. Excluding these samples, which may be expected to have undergone the most oxidation, the average and median ratio values are both 0.17 with a standard deviation of 0.04 . While previous studies (Deiana et al., 1995; van Schaik et al., 2008) have shown that humic substances have the potential to reduce Fe(III) in acidic solutions (up to $70 \%$ of $\mathrm{Fe}$ (III) in solutions with $\mathrm{pH} \leq 2.5$ in the Deiana et al. study), these studies utilized relatively high concentrations of humic or fulvic acid (e.g., 500 and $1000 \mathrm{mg} / \mathrm{L}$, respectively) and high ratios of organic acids to $\mathrm{Fe}$ (III) (>200 and 20 by mass, respectively), far in excess of that found in the waters associated with the films. As described below and reported by Grathoff et al. (2007) and Kleja et al. (2012), the natural film samples are iron oxyhydroxide solids and while some organic matter may be present within or on the surface of the films, it is likely a trace to minor component. The consistency of the Fe(II) to Fe(III) ratios seems highly 
unlikely unless an intrinsic aspect of the film. And, the presence of $\mathrm{Fe}(\mathrm{II})$ was verified by the TEM EELS analyses, as described below.

SEM-EDS analysis of a film collected from an interior wetland (sample JB1) resulted in atomic percentages, excluding hydrogen, carbon and oxygen, of from 78 to $89 \%$ iron and 11 to $22 \% \mathrm{Si}$. The average measured $\mathrm{Si} /(\mathrm{Si}+\mathrm{Fe})$ of 0.22 is close to the value of 0.25 determined by Easterly (2005), suggesting silica is part of the structure, partially substituting for Fe (Campbell et al., 2002; Grathoff et al., 2007), rather than being adsorbed onto the film. No other elements were detected.

TEM-EELS spectra, as in Fig. 2, confirmed the presence of both $\mathrm{Fe}(\mathrm{II})$ and $\mathrm{Fe}(\mathrm{III})$ in the films, based on the distance between the Fe(II) L3 and the Fe(III) L3 peak which, according to Garvie et al. (1994) are located at $1.7 \mathrm{eV}$ apart at $707.8 \mathrm{eV}$ and $709.5 \mathrm{eV}$, respectively. The broad peak located $\sim 2 \mathrm{eV}$ above the Fe(III) L3 peak encompasses a group of minor L3 peaks identified by Garvie and Busick (1998).

Brightfield TEM imaging revealed regular lattice structures, indicating that the films are nanocrystalline (Figure 3). EFED patterns were analyzed to determine the diffraction spacings for five film samples (Table 5). Inter-planar spacings averaging $0.273 \pm 0.009 \mathrm{~nm}$ were measured in every sample analyzed and spacings averaging $0.371 \pm 0.009$ and $0.441 \pm 0.004 \mathrm{~nm}$ were measured in all but one or two samples analyzed, although not in every spot analysis in every sample. A diffraction ring often found at $0.33 \mathrm{~nm}$ is attributed to the carbon coating, as this corresponds to diffraction rings measured in our carbon support films. Grathoff et al. (2007) reported three diffraction spacings at $\sim 0.14,0.26$, and $0.45 \mathrm{~nm}$ for their film samples. We could not confirm the 0.14 -nm spacing as this fell outside of the radial integration used to analyze the 
EFED patterns. One additional spacing of $0.506 \pm 0.019 \mathrm{~nm}$ was determined for three samples (Table 5).
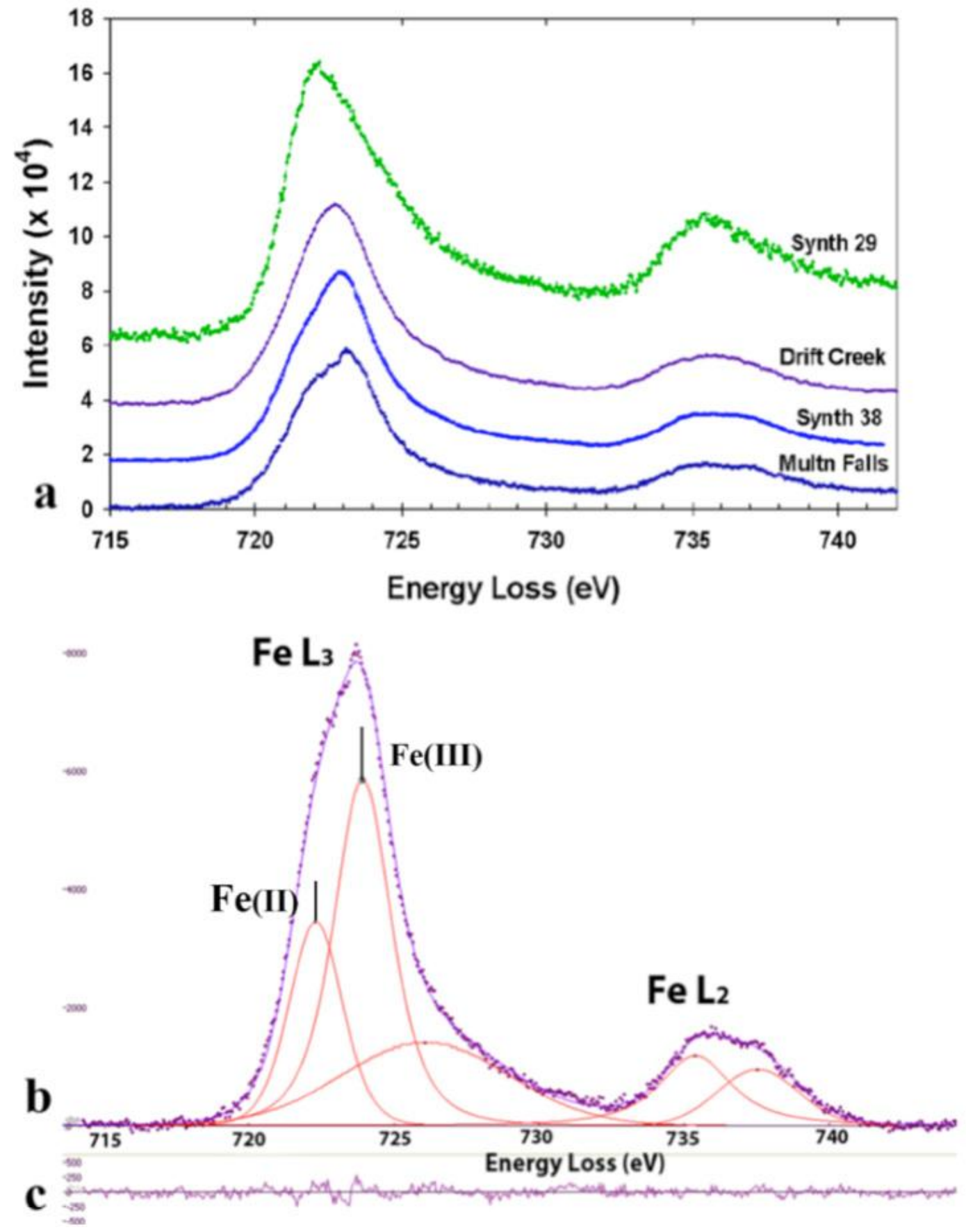

Figure 2. a) Electron energy loss spectrometry (EELS) spectra for two natural iron films (Drift Creek and Mult. Falls) and two synthetic iron films (Synth 29 and 38). Note that peaks are shifted $\sim 12 \mathrm{eV}$ due to beam drift.; b) detail of EELS spectrum for Mult Falls 
sample showing showing Fe(II) and Fe(III), shown by peaks FeL2 and FeL3 respectively, peaks fitted with Fityk software. c) Residual errors of the peak fit.

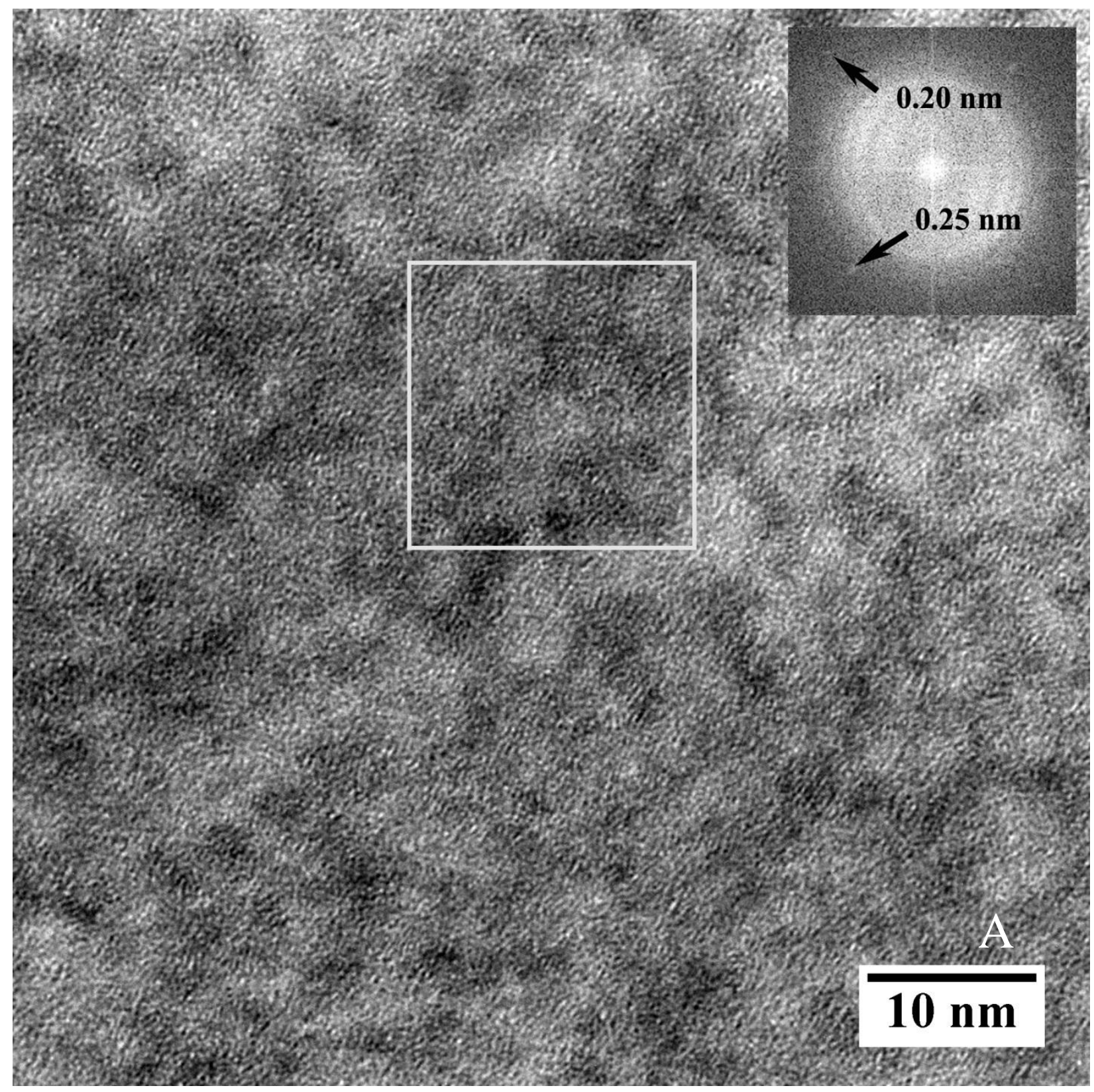




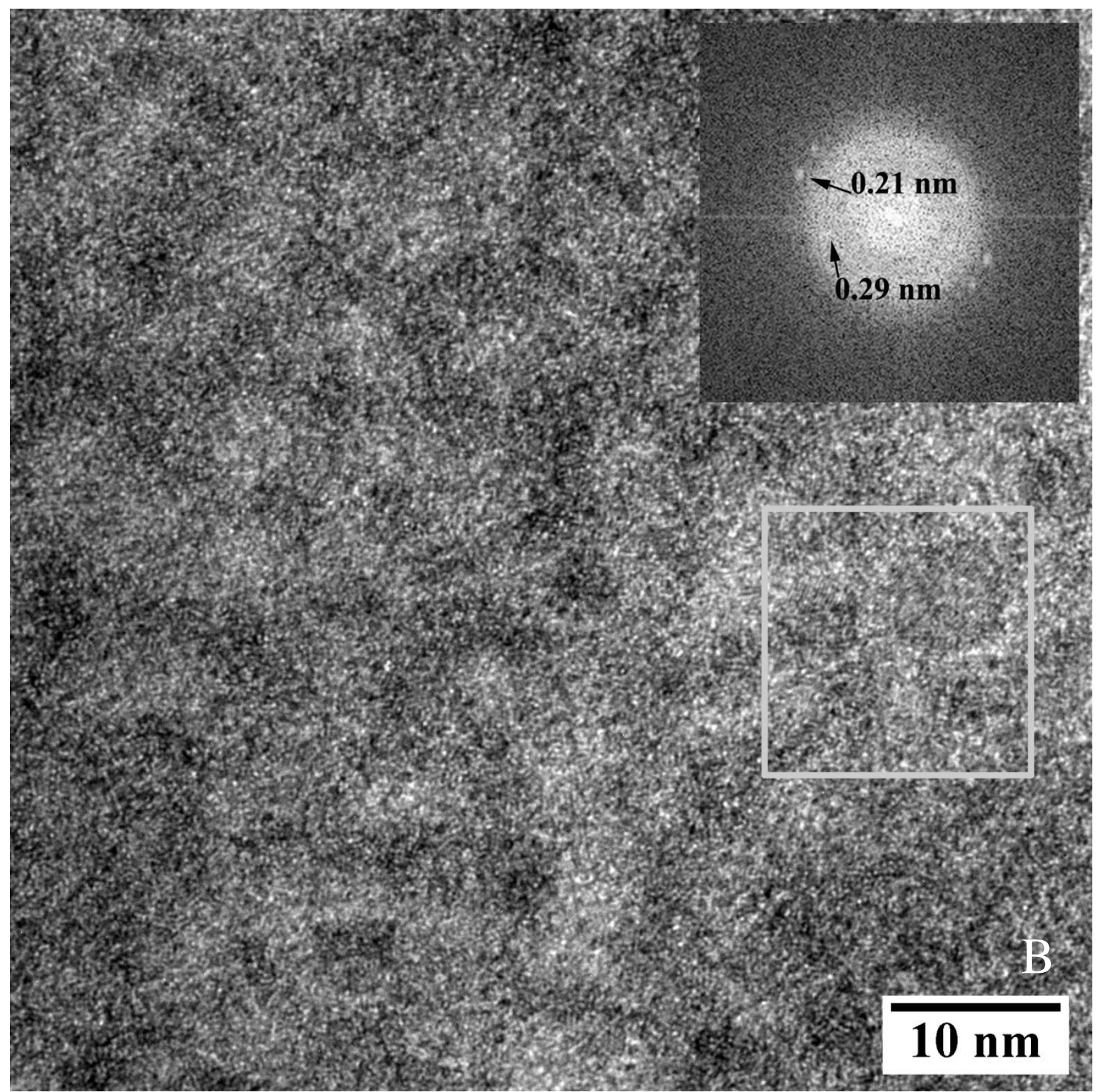

Figure 3. Brightfield TEM images (450 kx) of a) natural floating iron film sample NatJ3 and b) synthesized iron film sample Syn 29. Thicker areas of film form the darker regions and thinner areas are the lighter regions. Inset FFT diffractograms show diffraction spots indicating crystalline or pseudocrystalline regions within the outlined squares. 
Table 5. Interplanar distances (in $\mathrm{nm}$ ) determined via TEM-EFED. Values in parentheses are standard deviations $(\mathrm{nm})$. If rings were not identified in all measurements made on a sample, the number of detections is also noted.

\begin{tabular}{|c|c|c|c|c|c|}
\hline Sample (\# of measurements) & 1st & 2nd & 3rd & 4th & 5th \\
\hline \multicolumn{6}{|l|}{ Natural Films } \\
\hline $\mathrm{DC}(\mathrm{n}=7)^{*}$ & $\begin{array}{c}0.262 \\
(0.005)\end{array}$ & $\begin{array}{c}0.322 \\
(0.018 \\
n=5)\end{array}$ & -- & $\begin{array}{c}0.445 \\
(0.008 ; \\
n=3)\end{array}$ & -- \\
\hline $\operatorname{MF}(n=3)$ & $\begin{array}{c}0.276 \\
(0.008)\end{array}$ & -- & $\begin{array}{c}0.383 \\
(0.011)\end{array}$ & -- & $\begin{array}{c}0.499 \\
(0.008)\end{array}$ \\
\hline $\operatorname{MS}(n=1)$ & 0.265 & 0.309 & -- & 0.440 & -- \\
\hline TC-1 $(n=3)$ & $\begin{array}{l}0.276 \\
(\mathrm{n}=1)\end{array}$ & $\begin{array}{c}0.323 \\
(0.014)\end{array}$ & $\begin{array}{l}0.374 \\
(\mathrm{n}=1)\end{array}$ & 0.443 & -- \\
\hline JB-1 $(n=2)$ & $\begin{array}{l}0.285 \\
(0.20)\end{array}$ & $\begin{array}{l}0.326 \\
(n=1)\end{array}$ & $\begin{array}{l}0.366 \\
(n=1)\end{array}$ & $\begin{array}{l}0.434 \\
(\mathrm{n}=1) \\
0.444\end{array}$ & $\begin{array}{l}0.491 \\
(n=1)\end{array}$ \\
\hline JB-2 $(n=3)$ & $\begin{array}{c}0.272 \\
(0.028)\end{array}$ & $\begin{array}{l}0.356 \\
(0.08) \\
\end{array}$ & $\begin{array}{l}0.362 \\
(n=1)\end{array}$ & $\begin{array}{c}(0.009 ; \\
\mathrm{n}=2)\end{array}$ & $\begin{array}{l}0.527 \\
(n=1)\end{array}$ \\
\hline $\begin{array}{r}\text { Mean: } \\
\text { (Standard deviation): }\end{array}$ & $\begin{array}{c}0.273 \\
(0.008)\end{array}$ & $\begin{array}{c}\mathbf{0 . 3 2 7} \\
(\mathbf{0 . 0 1 7 )}\end{array}$ & $\begin{array}{c}0.371 \\
(0.009)\end{array}$ & $\begin{array}{c}0.441 \\
(0.004)\end{array}$ & $\begin{array}{c}0.506 \\
(0.019)\end{array}$ \\
\hline \multicolumn{6}{|l|}{ Synthesized Films } \\
\hline Syn4 $(n=2)$ & $\begin{array}{c}0.255 \\
(0.002) \\
0.255\end{array}$ & $\begin{array}{c}0.323 \\
(0.011) \\
0.333\end{array}$ & -- & $\begin{array}{c}0.418 \\
(0.008) \\
0.458\end{array}$ & -- \\
\hline Syn5 $(n=4)$ & $(0.003)$ & $(0.005)$ & & $(0.004)$ & -- \\
\hline Syn13 $(n=1)$ & 0.271 & 0.324 & -- & -- & 0.539 \\
\hline Syn $23(n=1)$ & 0.259 & 0.355 & -- & 0.432 & -- \\
\hline Syn24 $(n=2)$ & $\begin{array}{c}0.272 \\
(0.013)\end{array}$ & $\begin{array}{c}0.353 \\
(0.033)\end{array}$ & -- & -- & $\begin{array}{c}0.483 \\
(0.009)\end{array}$ \\
\hline Syn29 $(n=2)$ & $\begin{array}{c}0.258 \\
(0.008)\end{array}$ & $\begin{array}{c}0.332 \\
(0.008)\end{array}$ & -- & -- & - \\
\hline Syn35 (n=2) & $\begin{array}{c}0.259 \\
(0.001)\end{array}$ & $\begin{array}{l}0.341 \\
(0.004)\end{array}$ & -- & $\begin{array}{c}0.442 \\
(0.019)\end{array}$ & -- \\
\hline Syn $37(n=1)$ & 0.261 & 0.331 & -- & -- & 0.485 \\
\hline Syn $38(n=3)$ & $\begin{array}{c}2.60 \\
(0.003) \\
\end{array}$ & $\begin{array}{l}0.347 \\
(0.014) \\
\end{array}$ & -- & $\begin{array}{c}0.448 \\
(0.013) \\
\end{array}$ & \\
\hline $\begin{array}{r}\text { Mean: } \\
\text { (Standard deviation): }\end{array}$ & $\begin{array}{c}0.261 \\
(0.006)\end{array}$ & $\begin{array}{c}0.338 \\
(0.012)\end{array}$ & -- & $\begin{array}{c}0.440 \\
(0.015)\end{array}$ & $\begin{array}{c}\mathbf{0 . 5 0 2} \\
(\mathbf{0 . 0 3 2})\end{array}$ \\
\hline
\end{tabular}

* Drift Creek (DC) sample data from Easterly (2005); sample collected along central Oregon coast.

\subsection{Comparison of Synthetic and Natural Films}

Solutions made using the MGR method produced floating material, however, the majority of the material appeared crystalline. TEM brightfield images taken of select samples produced by 
this method resembled those of natural film to $\sim 5,000 \mathrm{x}$. However, at higher magnifications, the material clearly had a higher degree of order / crystallinity than natural films. Two solutions (Syn $5 \& 8$ ) yielded fibrous crystals; TEM-EFED analyses of material from Syn 5 resulted in electron diffraction peaks corresponding to interplanar spacings of 0.412 and $0.423 \mathrm{~nm}$.

The addition of UVB light (UVB method) also produced floating material that appeared more crystalline than natural films. Enough material was produced to analyze the material via XRD, which indicated a mixture lepidocrocite and goethite. This verifies the results of Braterman et al. (1983) who determined that Fe(II)-rich solutions at circum-neutral pHs under UVB light $(<300 \mathrm{~nm})$ led to the precipitation of $\gamma$-FeOOH (lepidocrocite). Goethite, as well as lepidocrocite, can form from oxidation of green rusts in the presence of carbonates (Cornell and Schwertmann, 2003).

Films that best resembled natural films both visually and at high magnification and which covered $75-100 \%$ of the solution surface were obtained with the addition of humic acid (modified-UVB method), under both aerobic and anaerobic conditions. The systematic variations of the modified-UVB method produced films of varying thickness in 13 of the 22 solutions. Films formed within three days under aerobic conditions using either $\mathrm{Fe}(\mathrm{II})$ or a mixture of $\mathrm{Fe}(\mathrm{II})$ and $\mathrm{Fe}(\mathrm{III})$ salts. No films were formed when only $\mathrm{Fe}(\mathrm{III})$ salt $\left(\mathrm{Fe}_{2}\left(\mathrm{SO}_{4}\right)_{3} \cdot 5 \mathrm{H}_{2} \mathrm{O}\right)$ was used as the iron source. Solutions under anaerobic conditions took as long as 25 days to form clearly discernable surface films, but these tended to grow significantly thicker than those formed under aerobic conditions. Several of these samples were left in place for several additional weeks and continued to thicken. Films were successfully formed in solutions containing no silica.

SEM imaging indicated little discernable differences in the morphologies of various films synthesized with the modified-UVB method and very little morphological difference, if any, 
between these synthesized films and natural films, aside from debris present on natural samples, There were no structures present that resembled microbes or other organisms, and films readily formed on solutions to which microbicides were added. EDS analyses indicate the compositions of these films (excluding $\mathrm{H}, \mathrm{O}$, and $\mathrm{C}$ ) to be $65-89 \% \mathrm{Fe}, 11-35 \% \mathrm{Si}$. Some very minor peaks of Ca were found in some but not all of the EDS spectra.

TEM brightfield imaging of films synthesized via the modified-UVB method reveal them to be poorly ordered / nano-crystalline, as seen in natural films (Fig. 3). EFED analysis of six films synthesized using the modified-UVB method identified spacings of $\sim 0.26 \mathrm{~nm}$ in all samples and $\sim 0.44 \mathrm{~nm}$ in all but one (Table 5). Both spacings are consistent with those found in natural floating iron film samples as part of this study and as previously reported by Grathoff et al. (2007). Three additional spacings, at $0.357,0.598$, and $1.178 \mathrm{~nm}$ were identified in a single sample (Syn 23) to which $\mathrm{HCl}$ was added during mixing to regulate $\mathrm{pH}$. A spacing of $0.853 \mathrm{~nm}$ was also identified in one other synthesized film sample (Syn 38). These may be attributed to green rust (Cornell and Schwertmann, 2003).

\section{Discussion}

\subsection{Chemistry of Associated Waters}

Water chemistries were evaluated using the Visual MINTEQ program, version 3.1

(Gustafsson, 2013). Modeling of Fe speciation and pe values were made both with and without accounting for metal - organic complexation using the Stockholm Humic Model (Gustafsson, 2001). In using the Stockholm Model, the ratio of active dissolved organic matter (DOM) to dissolved organic carbon was set to the default value of 1.65 and active DOM was modeled as strictly fulvic acid, strictly humic acid, and an arbitrary mixture of $40 \%$ humic and $60 \%$ fulvic acids using the 'typical' acid-base parameter databases and the 'generic' complexation databases 
provided in Visual MINTEQ. Given the moderate DOC concentrations of the natural samples (only one, had DOC concentration $>10 \mathrm{mg} / \mathrm{L}$ ), the organic-complexation made little difference in the concentration of free $\mathrm{Fe}^{2+}$ (>95\% of total $\mathrm{Fe}(\mathrm{II})$, except for JB-1 (87 and 89\%, using strictly fulvic and humic acid models, respectively). The inclusion of Fe-organic complexation had expectedly, a greater impact on Fe(III) speciation, resulting in an average decrease in pe of 0.68 (ranging from $<0.1$ to 1.8 or $\sim 5$ to $90 \mathrm{mv}$ Eh). These changes were on the order observed using different thermodynamic databases with variable numbers of non-organic $\mathrm{Fe}(\mathrm{III})$ species (e.g., PhreeqC vs Minteq4 databases yielded differences of 1.1 pe for the JB-1 sample).

In all cases, the waters were oversaturated with respect to ferrihydrite (saturation indices 1.8 4.7), and other Fe(III) phases such as goethite and lepidocrocite. This may be due to the presence of colloidal Fe(III). However, we did make great effort to exclude colloids, filtering through 0.1$\mu \mathrm{m}$ polysulfone filters, and will assume the oversaturation of the waters with respect to ferrihydrite is reflective of the actual aqueous compositions. As shown in Fig. 1, a ferrihydrite flocculent was found at some sites, but this was invariably associated with filamentous bacterial colonies and tended to occur somewhat away from the area of primary film production (i.e., at the discharge end of spring pools).

A plot of measured $\mathrm{pH}$ and pe values calculated from iron speciation analyses (assuming active DOM to be humic acid) shows that nearly all of the samples plot in the $\mathrm{Fe}^{2+}$ aqueous species field and inside but very near the stability boundary for ferrihydrite (Fig. 4). A 10-fold decrease in the assumed value for $\mathrm{Fe}^{2+}$ activity $\left(10^{-4}\right)$, similar to the value measured in the WW sample, would shift the solid phase stability boundary to the right of some sample points; a drop in assumed temperature to $5^{\circ} \mathrm{C}$ - similar to the conditions for both TC samples - would have a similar result. Thus, while there appears to be more than sufficient dissolved Fe(III) to precipitate 
ferrihydrite, a favorable redox state is tenuous at best, reflective of these dynamic systems where ferrous iron-rich groundwaters are surfacing.

Ion activity products (IAPs) and SIs for green rusts were calculated following Bourrie et al. (Table 2, 1999). The resulting values (Table 6a) suggest that the waters are at or near saturation with respect to carbonate green rust, $\mathrm{GR} 1\left(\mathrm{CO}_{3}{ }^{2-}\right)(\log \mathrm{K}=9.19 \pm 0.4)$, with a mean SI of 0.23 \pm 0.57 (or $0.08 \pm 0.31$ if a single sample, MS-1, is removed) as calculated using ion activities and pe produced with the SHM. Similar calculations made ignoring organic complexation (without SHM) yield a slightly higher mean SI of 0.45 . Similarly, the waters are slightly oversaturated with respect to $\mathrm{GR} 2\left(\mathrm{SO}_{4}{ }^{2-}\right.$ ) (mean $\mathrm{SI}=0.40$ or 0.61 , with and without $\mathrm{SHM}$ ) but undersaturated with respect to $\mathrm{GR} 1\left(\mathrm{Cl}^{-}\right)$(mean $\mathrm{SI}=-1.10$ or -0.93 , with and without $\mathrm{SHM}$ ). It seems reasonable that the film environments, with their transitional $\mathrm{pH}$-Eh conditions and, in most cases, influx of ferrous iron-rich groundwaters, would be suitable for the formation of green rust. Similar calculations for synthesis solutions (Table 6b) made using the modified UVB method yield mean SIs for carbonate and sulfate green rust that are either negative or positive, with and without the SHM and again clearly undersaturated with respect to the chloride green rust. Interestingly, the three samples (Syn-35, -37, and -38) produced with the same method but with the order of mixing reagents reversed appear very near saturation with respect to chloride greenrust (mean SI $=0.17$ or 0.35$) .6$

Excluding the possible incorporation of silica and carbonate (and organics) in the iron film structure, we may write a generalized formula $\mathrm{Fe}^{2+}{ }_{1-\mathrm{x}} \mathrm{Fe}^{3+}{ }_{\mathrm{x}}(\mathrm{OH})_{2+\mathrm{x}}$. Based on the median $\mathrm{Fe}(\mathrm{II}): \mathrm{Fe}(\mathrm{III})$ ratio of 0.16 as measured in this study, a nominal formula normalized to $3(\mathrm{OH})$ would be $\mathrm{Fe}^{2+}{ }_{0.15} \mathrm{Fe}^{3+}{ }_{0.90}(\mathrm{OH})_{3}$. Following the examples of Bourrie et al. $(1999,2004)$ for green rusts, the log ion activity product (IAP) may then be expressed: 


$$
\log (\mathrm{IAP})=1.05 \log \left\{\mathrm{Fe}^{+2}\right\}+0.90 \mathrm{pe}+3 \mathrm{pH}
$$

The average log IAPs calculated with and without organic complexation are $19.87 \pm 0.89$ and $20.43 \pm 0.51$, respectively (Table 6a). We note that the IAPs are calculated from samples collected at different temperatures, which likely accounts for some of the variability, although no trend between IAPs and temperature was discernable over the relatively limited range of temperatures measured. Plots of IAP vs pe, $\mathrm{pH}$, and $-\log \left\{\mathrm{Fe}^{2+}\right\}$ show no trend (Fig. 5), suggesting equilibrium control. Similar calculations were made for solutions from which floating iron films were synthesized. The five solutions from the Modified-USB method that were analyzed yielded essentially the same results, a mean log IAP value of $20.38 \pm 0.43$, when excluding organic complexation. However, a lower value of $18.54 \pm 1.25$ was calculated from activities derived using the SHM model, with two samples, Syn24 and Syn27, yielding log IAPs $<18$ (Table 6b). Interestingly, solutions prepared in the same manner but oxygentated under normal atmospheric conditions and those prepared with the same reagents but in reverse order yielded log IAPs that were an order of magnitude higher ( 21; Table 6).

Despite the limited range of IAP values calculated for waters associated with natural films, it seems unlikely that a film at the air-water interface would control the chemistry of the bulk waters underneath. Further evidence is provided by the fact that films were present on the surface of some synthesis solutions that yielded much higher IAP values. It is more likely that the bulk water chemistry - at least in the natural systems and some synthesized solutions - is controlled by the presence of carbonate green rusts, which likely exist as nano-particles throughout the bulk solution. The speciation modeling and the resulting IAP values nonetheless provide a useful way 
of characterizing the waters associated with actively forming iron films and indicate that the bulk chemistries of these waters have a relatively narrow compositional range and redox states that occur near the $\mathrm{Fe}$ (II) / Fe(III) boundary and near the limits of stability for the formation of amorphous $\mathrm{Fe}(\mathrm{OH})_{3}$ solids.

\subsection{Floating Film Structure}

The films are nanocrystalline with the most consistent measured interplanar spacings being 0.26-0.27, 0.33-0.35, and $\sim 0.44 \mathrm{~nm}$. Grathoff et al. (2007) also consistently measured nominal spacings of $0.14 \mathrm{~nm}$ as well as $0.26 \mathrm{~nm}$, though the former spacing falls outside of the radial integration we used to analyze TEM-EFED patterns. Both the $0.14-$ and $0.26 / 0.27-n m$ spacings approximate the 0.15 - and 0.25 -nm spacings reported for two-line ferrihydrite, while the 0.33 $0.35 \mathrm{~nm}$ spacing - which we measured but attributed to carbon coating of TEM samples corresponds to the 012 spacing of more crystalline ferrihydrite (Cornell and Schwertmann, 2003; Drits et al., 1993; Eggleton and Fitzpatrick, 1988; Michel et al., 2007; Zhao et al., 1994). Towe and Bradley (1967) report a d-spacing of $0.461 \mathrm{~nm}$ for synthesized ferrihydrite $(\alpha-\mathrm{FeOOH})$ and Eggleton and Fitzpatrick (1988) also noted two broad peaks at 0.45 and $0.325 \mathrm{~nm}$ in XRD patterns of synthesized 6-line ferrihydrite.

Both TEM and analyses of films dissolved in $\mathrm{HCl}$ show that the films are composed of mixed-valent iron, consistent with the presence of green rust. Spacings averaging $0.506 \pm 0.019$ $\mathrm{nm}$, similar to $\sim 0.47-0.48 \mathrm{~nm}$ peaks reported for sulfate green rust, $\mathrm{GR}_{\mathrm{SO} 4}$ (Table 3 in Christiansen et al., 2009), were also measured in several of our samples. 
Table 6a. Measured $\mathrm{pH}$, pe calculated from $\mathrm{Fe}(\mathrm{II}): \mathrm{Fe}(\mathrm{III})$ ratios, log activities of select ions, and resulting $\log$ IAPs for various mixed-valent iron phases determined for natural samples. Log IAPs for green rusts (GR) phases follow Bourrie et al. (1999). Activities and pe calculated with Visual Minteq with and without the Stockholm Humic Model (SHM).

\begin{tabular}{|c|c|c|c|c|c|c|c|c|c|c|}
\hline Sample & $\mathrm{pH}$ & pe & $\begin{array}{c}\text { Log } \\
\left\{\mathrm{Fe}^{2+}\right\}\end{array}$ & $\begin{array}{l}\text { Log } \\
\left\{\mathrm{Cl}^{\prime}\right\}\end{array}$ & $\begin{array}{c}\mathrm{Log} \\
\left\{\mathrm{CO}_{3}{ }^{2-}\right\}\end{array}$ & $\begin{array}{c}\log \\
\left\{\mathrm{SO}_{4}{ }^{2-}\right\}\end{array}$ & $\begin{array}{l}\text { Log IAP } \\
\text { GR1(CI) }\end{array}$ & $\begin{array}{c}\log \text { IAP } \\
\text { GR1 }\left(\mathrm{CO}_{3}\right)\end{array}$ & $\begin{array}{c}\text { Log IAP } \\
\left.\text { GR2(SO }{ }_{4}\right)\end{array}$ & $\begin{array}{l}\text { Log IAP } \\
\text { Fe Film }\end{array}$ \\
\hline & & & & & \multicolumn{2}{|c|}{ Reported $\log K^{1}$ : } & $10.37 \pm 0.3$ & $9.19 \pm 0.4$ & $9.43 \pm 0.4$ & -- \\
\hline \multicolumn{11}{|c|}{ Natural Samples } \\
\hline JB-1: & 6.52 & 5.47 & -3.92 & -4.22 & -6.62 & -5.22 & 9.43 & 9.84 & 10.07 & 20.37 \\
\hline with SHM: & & 4.01 & -3.97 & -4.21 & -6.61 & -5.22 & 9.02 & 9.31 & 9.54 & 19.01 \\
\hline$J B-2^{2}$ & 6.30 & 6.09 & -3.73 & -3.50 & -7.33 & -5.20 & 9.52 & 9.68 & 10.04 & 20.47 \\
\hline MF & 6.97 & 4.59 & -4.72 & -3.51 & -6.74 & -5.60 & 9.49 & 9.63 & 9.82 & 20.08 \\
\hline with SHM: & & 2.94 & -4.74 & -3.51 & -6.74 & -5.60 & 9.06 & 9.06 & 9.25 & 18.58 \\
\hline MS-1 & 6.88 & 5.16 & -3.57 & -3.80 & -6.53 & -4.26 & 10.51 & 10.79 & 11.17 & 21.46 \\
\hline with SHM: & & 5.08 & -3.57 & -3.80 & -6.53 & -4.26 & 10.51 & 10.79 & 11.17 & 21.46 \\
\hline MS-2 & 6.51 & 6.84 & -4.57 & -3.53 & -7.10 & -4.23 & 9.28 & 9.54 & 10.02 & 20.89 \\
\hline with SHM: & & 6.76 & -4.58 & -3.53 & -7.10 & -4.23 & 9.25 & 9.51 & 9.99 & 20.80 \\
\hline $\mathrm{NW} 26^{\text {th }} \mathrm{a}$ & 6.36 & 5.44 & -4.19 & -2.94 & -7.51 & -4.32 & 9.16 & 9.13 & 9.63 & 19.58 \\
\hline with SHM: & & 4.92 & -4.19 & -2.94 & -7.51 & -4.32 & 9.02 & 8.92 & 9.45 & 19.11 \\
\hline $\mathrm{NW} 26^{\text {th }} \mathrm{b}$ & 6.57 & 5.80 & -4.19 & -2.94 & -7.42 & -4.34 & 9.67 & 9.65 & 10.16 & 20.05 \\
\hline with SHM: & & 5.61 & -4.64 & -2.94 & -7.39 & -4.34 & 9.16 & 9.13 & 9.64 & 19.88 \\
\hline RE & 6.54 & 5.11 & -3.56 & -2.83 & -6.91 & -4.62 & 10.09 & 10.07 & 10.45 & 20.48 \\
\hline with SHM: & & 4.65 & -3.56 & -2.83 & -6.91 & -4.62 & 9.98 & 9.92 & 10.30 & 20.07 \\
\hline
\end{tabular}




\begin{tabular}{|c|c|c|c|c|c|c|c|c|c|c|}
\hline TC-1 & 6.40 & 6.46 & -4.27 & -4.03 & -7.32 & -4.10 & 9.14 & 9.46 & 10.00 & 20.53 \\
\hline with SHM: & & 6.43 & -4.28 & -4.03 & -7.32 & -4.10 & 9.12 & 9.45 & 9.99 & 20.50 \\
\hline TC-2 & 6.74 & 5.76 & -4.53 & -3.93 & -6.95 & -4.10 & 9.40 & 9.71 & 10.18 & 20.64 \\
\hline with SHM: & & 4.35 & -4.55 & -3.93 & -6.95 & -4.09 & 9.04 & 9.22 & 9.70 & 19.36 \\
\hline WW & 6.55 & 6.40 & -5.08 & -4.26 & -7.20 & -4.91 & 8.56 & 8.95 & 9.34 & 20.07 \\
\hline \multirow[t]{5}{*}{ with SHM: } & & 6.25 & -5.08 & -4.26 & -7.20 & -4.91 & 8.52 & 8.90 & 9.28 & 19.94 \\
\hline & & & & & & Mean: & 9.44 & 9.64 & 10.04 & 20.43 \\
\hline & & & & & & w/ $/ \overline{\text { SHM: }}$ & 9.24 & 9.38 & 9.79 & 19.87 \\
\hline & & & & & & Stdev: & 0.52 & 0.51 & 0.49 & 0.51 \\
\hline & & & & & & w/ SHM: & 0.54 & 0.55 & 0.55 & 0.89 \\
\hline
\end{tabular}

1: Log K values from Bourrie et al., 1999

2: No DOC measurements made JB-2 solution.

Table $6 \mathrm{~b}$ Measured $\mathrm{pH}$, pe calculated from $\mathrm{Fe}$ (II):Fe(III) ratios, log activities of select ions, and resulting $\log$ IAPs for various mixed-valent iron phases determined for syntheses solutions. Log IAPs for green rust (GR) phases follow Bourrie et al. (1999). Activities and pe calculated with Visual Minteq with and without the Stockholm Humic Model (SHM).

\begin{tabular}{|c|c|c|c|c|c|c|c|c|c|c|}
\hline Sample & pH & pe & $\begin{array}{c}\mathrm{Log} \\
\left\{\mathrm{Fe}^{2+}\right\}\end{array}$ & $\begin{array}{l}\text { Log } \\
\left\{\mathrm{Cl}^{\prime}\right\}\end{array}$ & $\begin{array}{c}\log \\
\left\{\mathrm{CO}_{3}{ }^{2-}\right\}\end{array}$ & $\begin{array}{c}\text { Log } \\
\left\{\mathrm{SO}_{4}{ }^{2}{ }^{-}\right\}\end{array}$ & $\begin{array}{l}\text { Log IAP } \\
\text { GR1(CI) }\end{array}$ & $\begin{array}{c}\log \text { IAP } \\
\text { GR1 }\left(\mathrm{CO}_{3}\right) \\
\end{array}$ & $\begin{array}{c}\text { Log IAP } \\
\text { GR2 }\left(\mathrm{SO}_{4}\right)\end{array}$ & $\begin{array}{l}\text { Log IAP } \\
\text { Fe Film }\end{array}$ \\
\hline & & & & & \multicolumn{2}{|c|}{ Reported $\log K^{1}$ : } & $10.37 \pm 0.3$ & $9.19 \pm 0.4$ & $9.43 \pm 0.4$ & 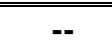 \\
\hline \multicolumn{11}{|c|}{ Synthesized Samples, Modified-USB Method $^{2}$} \\
\hline Syn23 & 7.22 & 4.99 & -5.20 & -3.16 & -6.66 & -3.82 & 9.69 & 9.79 & 10.26 & 20.68 \\
\hline with SHM: & & 2.96 & -5.27 & -3.16 & -6.66 & -3.81 & 9.13 & 9.06 & 9.53 & 18.80 \\
\hline Syn24 & 7.20 & 4.77 & -5.68 & -3.16 & -6.55 & -3.71 & 9.12 & 9.21 & 9.69 & 19.92 \\
\hline with SHM: & & 1.89 & -5.76 & -3.16 & -6.49 & -3.81 & 8.33 & 8.18 & 8.66 & 17.26 \\
\hline Syn27 & 7.10 & 5.44 & -5.98 & -3.13 & -6.96 & -3.42 & 8.79 & 8.87 & 9.46 & 19.91 \\
\hline with SHM: & & 2.91 & -6.02 & -3.13 & -6.96 & -3.42 & 8.12 & 7.99 & 8.58 & 17.60 \\
\hline Syn28 & 7.05 & 5.98 & -5.50 & -3.48 & -6.60 & -3.28 & 9.23 & 9.50 & 10.05 & 20.76 \\
\hline with SHM: & & 5.50 & -5.52 & -3.48 & -6.60 & -3.27 & 9.09 & 9.32 & 9.87 & 20.31 \\
\hline Syn29 & 7.44 & 4.42 & -5.43 & -2.64 & -7.65 & -3.44 & 9.90 & 9.65 & 10.35 & 20.60 \\
\hline \multirow[t]{4}{*}{ with SHM: } & & 2.54 & -5.45 & -2.63 & -7.65 & -3.45 & -9.41 & 9.00 & 9.70 & 18.88 \\
\hline & & & & & & Mean: & 9.35 & 9.40 & 9.96 & 20.38 \\
\hline & & & & & & $v / \overline{\text { SHM: }}$ & 8.81 & 8.70 & 9.26 & 18.54 \\
\hline & & & & & & Stdev: & 0.45 & 0.37 & 0.38 & 0.42 \\
\hline
\end{tabular}




\section{$\begin{array}{lllll}\text { w/ SHM: } & 0.57 & 0.60 & 0.62 & 1.25\end{array}$}

Synthesized Samples, Modified-USB Method, Reagents Added in Reverse Order ${ }^{2}$

\begin{tabular}{ccccccccccc}
\hline Syn35 & 7.00 & 3.93 & -3.32 & -3.33 & -6.23 & -3.84 & 10.83 & 10.95 & 11.35 & 21.05 \\
with SHM: & & 3.49 & -3.33 & -3.34 & -6.24 & -3.84 & 10.71 & 10.79 & 11.19 & 20.64 \\
Syn37 & 7.20 & 4.53 & -4.12 & -2.69 & -- & -3.81 & 10.75 & -- & 11.16 & 21.35 \\
with SHM: & & 4.31 & -4.13 & -2.69 & -- & -3.81 & 10.68 & -- & 11.07 & 21.14 \\
Syn38 & 7.60 & 3.84 & -4.99 & -2.36 & -7.67 & -3.88 & 10.63 & 10.27 & 10.89 & 20.38 \\
with SHM: & & 2.47 & -4.99 & -2.36 & -7.57 & -3.88 & 10.24 & 9.78 & 10.39 & 19.79
\end{tabular}

Synthesized Samples, Modified-USB Method, Aerobic (Open Atmosphere) ${ }^{2}$

\begin{tabular}{lllllllllll}
\hline Syn39 & 7.51 & 4.71 & -5.07 & -3.24 & -6.47 & -3.84 & 10.32 & 10.44 & 10.88 & 21.45 \\
with SHM: & & 4.65 & -5.07 & -3.25 & -6.47 & -3.84 & 10.30 & 10.42 & 10.86 & 21.39 \\
Syn40 & 7.63 & 4.21 & -4.34 & -3.19 & -6.15 & -3.84 & 11.18 & 11.30 & 11.69 & 22.13 \\
with SHM: & & 4.18 & -4.34 & -3.19 & -6.15 & -3.4 & 11.16 & 11.29 & 11.67 & 22.09
\end{tabular}

1: Log K values from Bourrie et al., 1999

2: Alkalinity not measured; $\left\{\mathrm{CO}_{3}{ }^{2-}\right\}$ calculated by charge balance, except for Syn37, which had negative charge balance. 


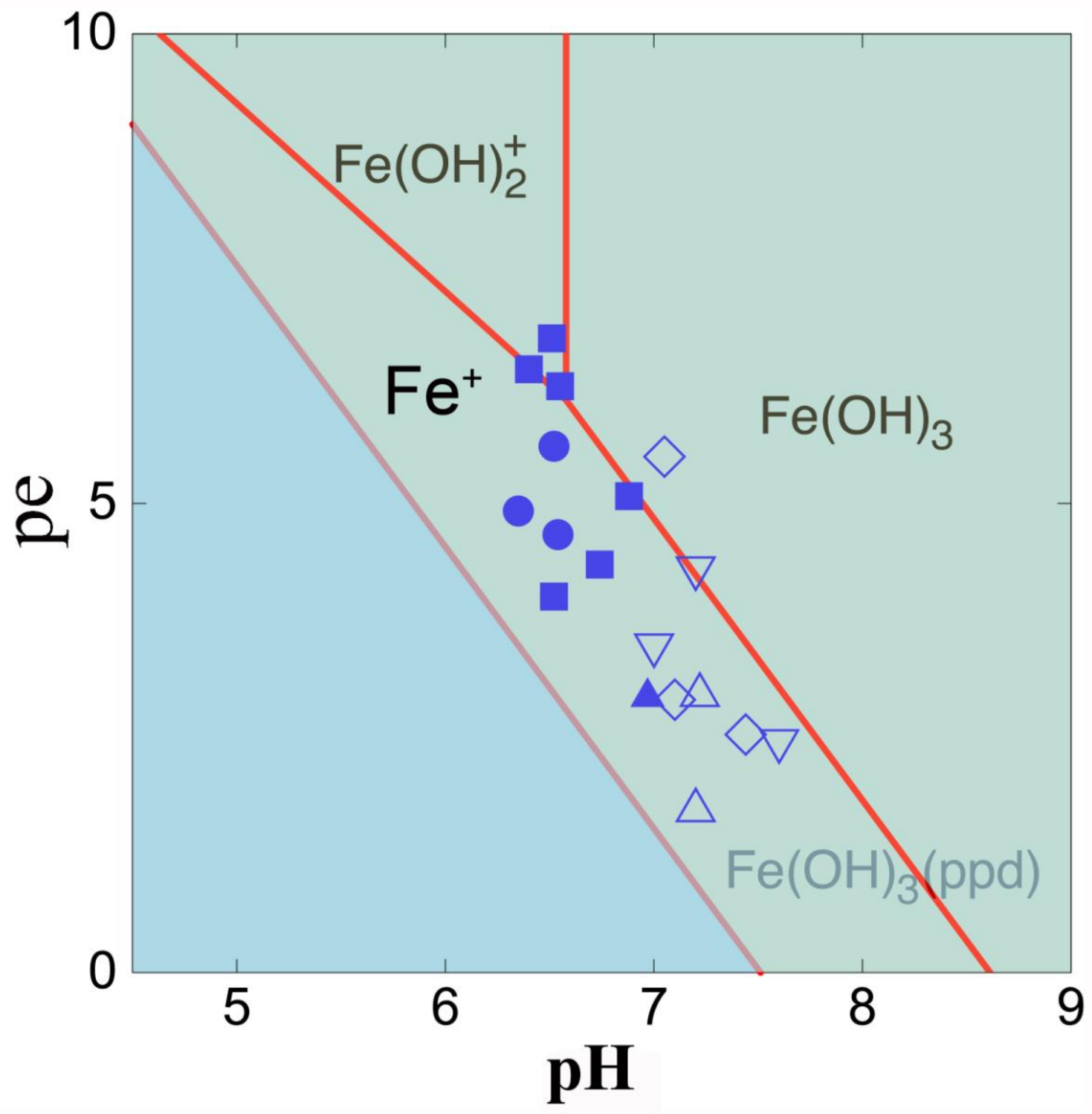

Figure 4. pe-pH diagram for $15^{\circ} \mathrm{C}$ and $\log \left\{\mathrm{Fe}^{2+}\right\}=-4$ showing aqueous samples relative to boundaries of aqueous $\mathrm{Fe}$ species and between $\mathrm{Fe}^{++}$and nanocrystalline $\mathrm{Fe}(\mathrm{OH})_{3}$ (ppd) ("ferrihydrite") (subdued), pe values calculated accounting for Fe-organic complexes. Solid circles represent coastal samples, squares inland wetlands, and the triangle represents single sample collected from Cascade Range. Open symbols represent select syntheses solutions: $\triangle$ - modified UVB method (Syn $23 \& 24$ ); $\diamond$-modified UVB with both $\mathrm{Fe}(\mathrm{II})$ and $\mathrm{Fe}(\mathrm{III})$ salts (Syn 27-29); $\nabla$-modified UVB with reagents added in reverse order (Syn 35, 37, 38) Lower $\left\{\mathrm{Fe}^{2+}\right\}$ or temperatures would shift the solid phase boundary to the right. 


\subsection{Insights from Synthesis Experiments}

Studies of thin films, particularly silicate thin films, suggest several possible mechanisms for the formation of films from inorganic nanoparticles at the air-water interface. Manne and Aksay (1997) note four routes in thin film synthesis: 1) Langmuir-Blodgett (LB) deposition; 2) covalent self-assembly; 3) alternating sequential adsorption; and 4) intercalation of organics into layered inorganic structures. Most researchers agree that it is the accumulation of hydrophobic lipoproteins - amphiphilic molecules - in surface micro- (or even mono-) layers that is the precursor to formation of thin films. Such molecules would be ubiquitous in wetland environments. Electrostatic attraction between iron nano-particles in the bulk solution and the surfactant surface, possibly in conjunction with "larger scale colloidal interactions" (Edler, 2006), could lead to the initial accumulation and subsequent growth of floating iron films. This may in part explain the role of humic acids (as a potential source) in the film synthesis, although floating, apparently more crystalline, floating iron films were produced in solutions prepared without humic acid.

The synthesis experiments provide some evidence for mechanisms that may allow for an $\mathrm{Fe}(\mathrm{II})$-bearing phase to remain metastable at the air-water interface. The ability of the film to form abiotically was demonstrated by successful synthesis in the presence of various microbicides. However, organic carbon in the form of humic acid appeared key to the production of amorphous or nanocrystalline floating films such as those found in nature. Organic matter and humic acid specifically have long been known to suppress the formation of crystalline $\mathrm{Fe}$ (III) phases (Schwertman, 1966, 1970). Karlsson and Persson (2012) found that Fe(III) formed stable complexes with dissolved organic matter, and speculated that Fe(III)-OM interactions suppress the hydrolysis and polymerization of Fe(III). Shimizu et al. (2013) found that humic acid inhibited goethite precipitation possibly by adsorption onto and blocking of reactive surface sites 
on intermediate ferrhihydrite and or decreases in specific surface area with increasing $\mathrm{C} / \mathrm{Fe}$ ratios. Beyond this, they found that a "green rust-like phase" formed from coprecipitated ferrihydrite and humic acid, and suggested that the coprecipitated humic acid entraps and concentrates $\mathrm{Fe}(\mathrm{II})$ and bicarbonate within diffusion limited microenvironments.

$\mathrm{Fe}(\mathrm{II})$ to $\mathrm{Fe}(\mathrm{III})$ ratios in green rust have most often been reported in the range of 0.8 to 3.6 (Cornell and Schwertmann, 2003), much higher than analyses indicate for the floating iron films $(0.16-0.20)$. However, more recent studies have found that $\mathrm{GR}\left(\mathrm{CO}_{3}{ }^{2-}\right)$ may be transformed by solid state oxidation to "ferric green rust" ("ex-GR-(FeIII)") via formation of FeII-III oxyhydroxycarbonates with a continuum of Fe(II) to Fe(III) ratios from 1.3 to 0 (i.e., $100 \%$ Fe(III)) (Legrand et al., 2004; Ruby et al., 2010; Ruby et al., 2006). The solid solution mechanism is promoted at the expense of the dissolution-precipitation mechanism by increasing $\left[\mathrm{CO}_{3}{ }^{2-}\right] /\left[\mathrm{GR}\left(\mathrm{CO}_{3}{ }^{2-}\right)\right]$ ratios, by increasing oxidation rates, and in the presence of adsorbed blocking species such as phosphate or silicate (Legrand et al., 2004). Of potential importance, Legrand et al. (2004) also demonstrated the solid-state reduction of exGR-Fe(III) back to $\mathrm{GR}\left(\mathrm{CO}_{3}{ }^{2-}\right)$.

Despite the rather constant values of silica in natural films via SEM/EDS, we were able to synthesize films without the addition of silica, so it does not appear to be an essential component. Indeed, silica concentrations of 0.5 and $2 \mathrm{mM}$ inhibited film formation, particularly when using only Fe(II) salts. Nonetheless, the thickest films were synthesized in the presence of relatively modest amounts of silica (up to $0.2 \mathrm{mM}$ ), suggesting silica may facilitate film stability if not initial formation. Legrand et al. (2004) found the solid state oxidation of $\mathrm{GR}\left(\mathrm{CO}_{3}{ }^{2-}\right)$ to exGR$\mathrm{Fe}(\mathrm{III})$ is favored over a dissolution-precipitation transformation in the presence of adsorbed blocking species such as phosphate or silicate. They further note that exGR-Fe(III) oxidized from 
$\mathrm{GR}\left(\mathrm{CO}_{3}{ }^{2-}\right)$ remains stable for long periods and that the conversion into more stable goethite which requires dissolution and precipitation to facilitate the different structure - occurred only in moderately heated (e.g., $60^{\circ} \mathrm{C}$ ) solutions and only in the absence of silica. Such a mechanism may well explain the apparent stability of Fe films in the presence of moderate silica. It is possible that the same mechanism occurred with the higher concentrations of silica in our synthesis experiments where enough silica was present to adsorb onto the very large surface areas of initially forming solids to prevent the association of nanoparticles and film formation.

Organic acids may also serve a critical role in maintaining ferrous iron in films via electron shuttling. UV light has been shown to induce photo-redox cycling of iron (Emmenegger et al., 2001; Voelker et al., 1997). When Fe(III)-humate complexes absorb a photon, it results in an excited ligand-to-metal transfer state of the complex in which $\mathrm{Fe}$ (III) gives up an electron to the humate material, allowing for the formation of $\mathrm{Fe}(\mathrm{II})$ and an oxidized organic radical to form. This radical may then undergo decarboxylation to form a secondary, carbon-centered radical and $\mathrm{CO}_{2}$. If the primary or secondary radicals are reductants, a second $\mathrm{Fe}(\mathrm{III})$ will be reduced to $\mathrm{Fe}(\mathrm{II})$, or, when oxygen is present, a superoxide radical $\left(\mathrm{HO}_{2} / \mathrm{O}_{2}-\right)$ is formed. This is generally the case if the organic radical can form a stable oxidized product by elimination of a single electron. The final dismutation product of the superoxide is the formation of hydrogen peroxide. In the presence of a high flux of superoxide (i.e. concentrations greater than $\mathrm{Fe}(\mathrm{II})-\mathrm{Fe}(\mathrm{III})$ concentrations), a steady-state ratio of $\mathrm{Fe}(\mathrm{II})-\mathrm{Fe}(\mathrm{III})$ is established (Voelker et al., 1997).

The photo-redox system described by Voelker et al. (1997) and Emmenegger et al. (2001) requires pe values of between $\sim+3$ and +5 at circum-neutral $\mathrm{pH}$, which is consistent with the conditions under which films have been observed. This would allow Fe(II) to remain in solution 
and the formation of green rust via oxidation of ferrous-rich waters or interaction between ferrihydrite and dissolved Fe(II):

$$
2 \mathrm{Fe}^{I I I} \mathrm{OOH}+4 \mathrm{Fe}^{I I}+6 \mathrm{OH}^{-}+2 \mathrm{H}_{2} \mathrm{O}+\mathrm{SO}_{4}^{2-} \Rightarrow \mathrm{Fe}_{4}^{I I} \mathrm{Fe}_{2}^{I I I}(\mathrm{OH})_{12} \mathrm{SO}_{4}
$$

Usman et al. (2012) have even reported the transformation of more stable goethite and hematite to green rust, though this does not seem pertinent to the iron film systems. As illustrated in Figure 6, such a photo-redox system could maintain a mixed-valent surface film either as a unique phase or, potentially as an Fe(II)-bearing ferrihydrite-humic complex, even if seasonally declining groundwater levels shut off the input of fresh ferrous-rich waters into the system.
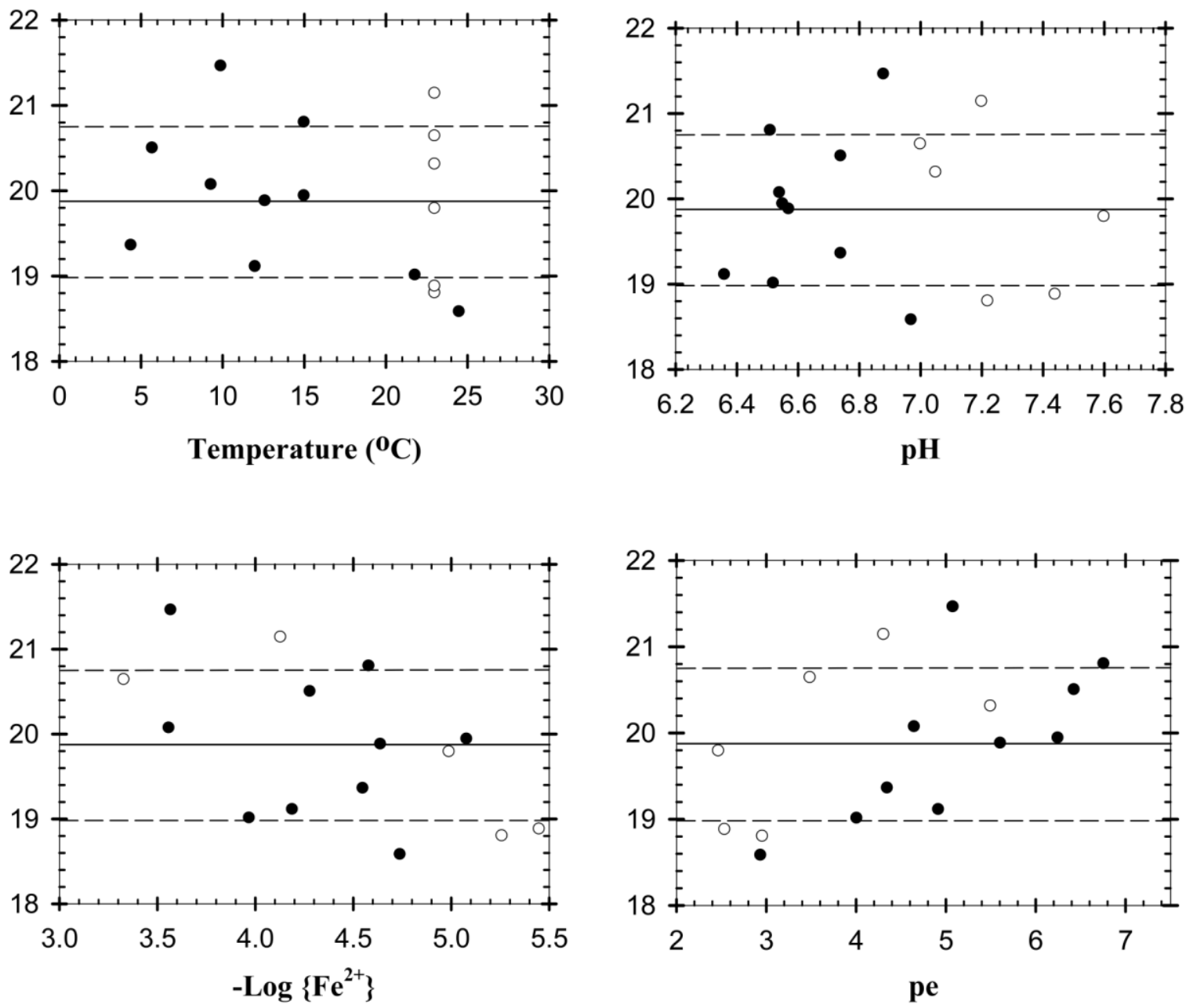
Figure 5. Plots of log ion activity products calculated by Equation 1 against temperature, $\mathrm{pH},-\log \left(\mathrm{Fe}^{\mathrm{II}}\right)$, and pe. Solid circles represent natural samples, open circles select synthesis solutions. The solid horizontal line shows the mean log IAP value of 19.87; the dashed lines define the $+/-1 \sigma$ range.

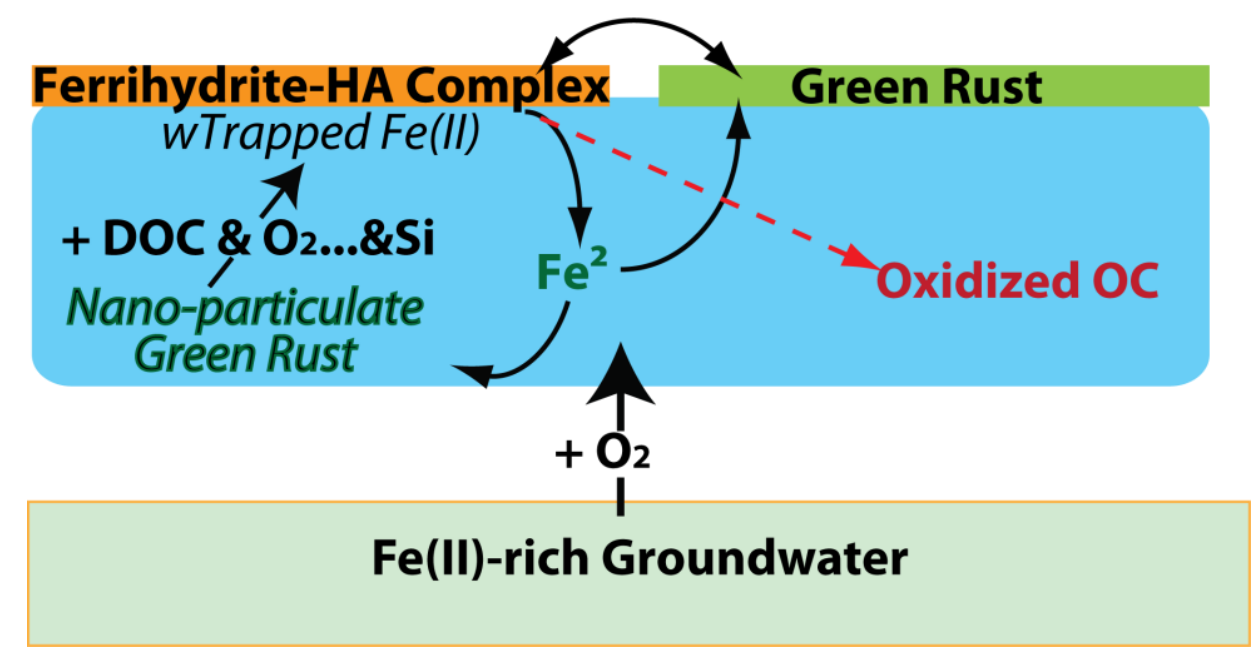

Figure 6. Mechanism, initially proposed by Gray (2008), for formation and persistence of mixed-valent iron surface films: Entrapment of $\mathrm{Fe}(\mathrm{II})$ during coprecipitation of ferrihydrite-humic acid complex and or cyclic transformation of initial ferrihydrite film to green rust driven by reduction of Fe(III) by organic material followed by photo- / atmospheric-oxidation.

\section{Conclusions}

Floating iron films form in quiet, circum-neutral (5.4 to 8.1) pH waters (Grathoff et al., 2007; Kleja et al., 2012) fed by Fe(II)-bearing groundwater, generally spring pools or surface seeps that also tend to have moderate levels of silica and dissolved organic carbon. The bulk waters underlying these films are characterized by intermediate redox conditions (Eh from +200 to +350 
$\mathrm{mV})$, reflective of such environments, and appear at or near saturation with respect to carbonate and sulfate green rust phases.

The films are nanocrystalline with the most consistent measured inter-planar spacings being 0.14 (Grathoff et al., 2007), 0.26-0.27, 0.33-0.35, and $0.44 \mathrm{~nm}$. While these may be interpreted as soley representing ferrihydrite, the $0.33-0.35$ and $0.44 \mathrm{~nm}$ spacings have also been reported for green rust phases (Christiansen et al., 2009). Both TEM-EELS and analyses of films dissolved in $\mathrm{HCl}$ show that the films are composed of mixed-valent iron, consistent with the findings of Grathoff et al. (2007).

Two mechanisms are proposed to explain the presence of mixed-valent iron at the airwater interface, both involving the presence of organics. The first is that humic acid coprecipitated with a ferric oxyhydroxide phase entraps and concentrates Fe(II) within diffusion limited microenvironments (Shimizu et al., 2013). The second, initially proposed by Gray (2008), building off earlier ideas of Voelker et al. (1997) and Emmenegger et al. (2001), is that of a cyclic transformation of initial ferrihydrite film to green rust via reduction by organic material followed by photo- / atmospheric-oxidation. Both processes may be at work.

The stability of iron films is likely dependent on the flux of Fe(II)-bearing groundwaters into surface pools, the concentration / flux of dissolved organic matter, potentially the presence of silica, which along with organic matter, may retard further crystallization, and the persistence of an appropriate physical environment (i.e., open water without intense rain and wind). 


\section{References}

Boult, S., Johnson, N., and Curtis, C., 1997, Recognition of a biofilm at the sediment-water interface of an acid mine drainage-contaminated stream, and its role in controlling iron flux: Hydrological Processes, v. 11, no. Compendex, p. 391-399.

Bourrie, G., Trolard, F., Genin, J. R., Jaffrezic, A., Maitre, V., and Abdelmoula, M., 1999, Iron control by equilibria between hydroxy-green rusts and solutions in hydromorphic solis: Geochimica et Cosmochimica Acta, v. 63, p. 3417-3427.

Bourrie, G., Trolard, F., Refait, P., and Feder, F., 2004, A solid-solution model for Fe(II)$\mathrm{Fe}(\mathrm{III})-\mathrm{Mg}(\mathrm{II})$ green rusts and fougerite and estimation of their Gibbs free energies of formation: Clays and Clay Minerals, v. 52, p. 382-394.

Burke, S. P., and Banwart, S. A., 2002, A geochemical model for removal of iron(II)(aq) from mine water discharges: Applied Geochemistry, v. 17, no. Compendex, p. 431-443.

Campbell, A. S., Schwertman, U., Stanjek, H., Friedl, J., Kyek, A., and Campbell, P. A., 2002, Si incorporation into hematite by heating Si-ferrihydrite: Langmuir, v. 18, p. 78047809.

Christiansen, B. C., Balic-Zunic, T., Petit, P. O., Frandsen, C., Morup, S., Geckeis, H., Katerinopoulou, A., and Stipp, S. L. S., 2009, Composition and structure of an ironbearing, layered double hydroxide (LDH) - Green rust sodium sulphate: Geochimica et Cosmochimica Acta, v. 73, p. 3579-3592.

Cornell, R. M., and Schwertmann, U., 2003, The Iron Oxides: Structure, Properties, Reactions, Occurrences and Uses, Weinheim, Germany, Wiley-VCH, 664 p.:

Deiana, S., Gessa, C., Manunza, B., Rausa, R., and Solinas, V., 1995, Iron(III) reduction by natural humic acids: a potentiometric and spectroscopic study: European Journal of Soil Science, v. 46, p. 103-108.

Drits, V. A., Sakharov, B. A., Salyn, A. L., and Manceau, A., 1993, Structural model for ferrihydrite: Clay Minerals, v. 28, no. GEOBASE, p. 185-207.

Easterly, H., 2005, Characterization of Iron-Bearing Films Found on Ephemeral Pools, Central Coast, Oregon [M.S.: Portland State University, $110 \mathrm{p}$.

Edler, K. J., 2006, Nanoscum: Solid nanostructured films at the air-water interface: Soft Matter, v. 2, p. 284-292.

Eggleton, R. A., and Fitzpatrick, R. W., 1988, New data and a revised structural moel for ferrihydrite: Clays and Clay Minerals, v. 36, p. 111-124.

Emmenegger, L., Schonenberger, R., Sigg, L., and Sulzberger, B., 2001, Light-induced redox cycling of iron in circumneutral lakes: Limnology and Oceanography, v. 46, p. 49-61.

Garvie, L., and Craven, A., 1994, Use of electron-energy loss near-edge fine structure in the study of minerals: American Mineralogist, v. 79, p. 411-425.

Garvie, L. A. J., and Buseck, P. R., 1998, Ratios of ferrous to ferric iron from nanometre-sized areas in minerals: Nature, v. 396, p. 667-670.

Giovanela, M., Parlanti, E., Soriano-Sierra, E. J., Soldi, M. S., and Sierra, M. M. D., 2004, Elemental compositions, FT-IR spectra and thermal behavior of sedimentary fulvic and humic acids from aquatic and terrestrial environments: Geochemical Journal, v. 38 , p. 255-264. 
Grathoff, G., Baham, J., Easterly, H., Gassman, P., and Hugo, R., 2007, Mixed-valent Fe films (schwimmeisen) on the surface of reduced ephemeral pools: Clays and Clay Minerals, v. 55, p. 638-646.

Gray, Z. N., 2008, The Characterization and Hydrogeochemistry of Floating, Mixed-Valent Iron Films [M.S.: Portland State University, 258 p.

Jickells, T. D., An, Z. S., Andersen, K. K., Baker, A. R., Bergametti, G., Brooks, N. N., Cao, J. J., Boyd, P. W., Duce, R. A., Hunter, K. A., Kawahata, H., Kubilay, N., laRoche, J., Liss, P. S., Mahowald, N., Prospero, J. M., Ridgwell, A. J., Tegen, I., and Torres, R., 2005, Global Iron Connections Between Desert Dust, Ocean Biogeochemistry, and Climate Science, v. 308, p. 67-71.

Karlsson, T., and Persson, P., 2012, Complexes with aquatic organic matter suppress hydrolysis and precipitation of Fe(III): Chemical Geology, v. 322-323, p. 19-27.

Kleja, D. B., van Schaik, J. W. J., Persson, I., and Gustafsson, J. P., 2012, Characterization of iron in floating surface films of some natural waters using EXAFS: Chemical Geology, v. 326-327, p. 19-26.

Lear, G., Niyogi, D., Harding, J., Dong, Y., and Lewis, G., 2009, Biofilm bacterial community structure in streams affected by acid mine drainage: Applied and Environmental Microbiology, v. 75, no. Compendex, p. 3455-3460.

Legrand, L., Mazerolles, L., and Chausse, A., 2004, The oxidation of carbonate green rust into ferric phases: Solid-state reaction or transformation via solution: Geochimica et Cosmochimica Acta, v. 68, p. 3497-3507.

Lo, W., Nelson, Y. M., Lion, L. W., Shuler, M. L., and Ghiorse, W. C., 1996, Determination of iron colloid size distribution in the presence of suspended cells: Application to iron deposition onto a biofilm surface: Water Research, v. 30, no. Compendex, p. 24132423.

Manne, S., and Aksay, I. A., 1997, Thin films and nanolaminates incorporating organicinorganic interfaces: Current Opinion in Solid State and Materials Science, v. 2, p. 358-364.

Michel, F. M., Ehm, L., Liu, G., Han, W. Q., Antao, S. M., Chupas, P. J., Lee, P. L., Knorr, K., Eulert, H., Kim, J., Grey, C. P., Celestian, A. J., Gillow, J., Schoonen, M. A. A., Strongin, D. R., and Parise, J. B., 2007, Similarities in 2- and 6-Line Ferrihydrite Based on Pair Distribution Function Analysis of X-ray Total Scattering: Chemistry of Materials, v. 19, no. 6, p. 1489-1496.

Parkhurst, D. L., and Appelo, C. A. J., 2013, Description of input and examples for PHREEQC version 3 - A computer program for speciation, batch-reaction, one-dimensional transport, and inverse geochemical calculations.

Poulton, S. W., and Raiswell, R., 2002, The low-temperature geochemical cycle of iron: From continental fluxes to marine sediment deposition: American Journal of Science, v. 302, p. 774-805.

Rasband, W. S., 1997-2014, ImageJ, in Health, U. S. N. I. o., ed.: Bethesda, MA.

Ruby, C., Abdelmoula, M., Naille, S., Renard, A., Khare, V., Ona-Nguema, G., Morin, G., and Genin, J. R., 2010, Oxidation modes and thermodynamics of FeII-III oxyhydroxycarbonate green rust: Disssolution-precipitation versus in situ deprotonation: Geochimica et Cosmochimica Acta, v. 74, p. 953-966. 
Ruby, C., Upadhyaay, C., Gehin, A., Ona-Nguema, G., and Genin, J. R., 2006, In situ redox flexibility of FeII-III oxyhydroxycarbonate green rust and fougerite: Environmental Science and Technology, v. 40, p. 4696-4702.

Schwertman, U., 1966, Inhibitory effect of soil organic matter on crystallization of amorphous ferric hydroxide: Nature, v. 212, p. 645.

Schwertman, U., 1970, Influence of various simple organic anions on formation of goethite and hematite from amosphous ferric hydroxide: Geoderma, v. 3, p. 207-214.

Shimizu, M., Zhou, J., Schroder, C., Obst, M., Kappler, A., and Borch, T., 2013, Dissimilatory reduction and transformation of ferrihydrite-humic acid coprecipitates: Environmental Science and Technology, v. 47, p. 13375-13384.

Stronhmeier, S., Knorr, K. H., Reichert, M., Frei, S., Fleckenstein, J. H., Peiffer, S., and Matzner, E., 2013, Concentrations and fluxes of dissolved organic carbon in runoff from a forested catchment: Insights from high frequency measurements: Biogeosciences, v. 10, p. 905-916.

Taylor, K. G., and Konhauser, K. O., 2011, Iron in Earth surface sstems: A major player in chemical and biological processes: Elements, v. 7, no. 83-88.

Thurman, E. M., 1985, Organic Geochemistry of Natural Waters, Boston, Dordrecht Developments in Biogeochemistry.

To, T. B., Nordstrom, D. K., Cunningham, K. M., Ball, J. W., and McCleskey, R. B., 1999, New method for the direct determination of dissolved Fe(III) concentration in acid mine waters: Environmental Science and Technology, v. 33, p. 807-813.

Towe, K. M., and Bradley, W., 1967, Mineralogical constitution of collodial "hydrous ferric oxides": Journal of Colloid and Interface Science, v. 24, p. 384-392.

Usman, M., Hanna, K., Abdelmoula, M., Zegeye, A., Faure, P., and Ruby, C., 2012, Formation of green rust via mineralogical transformation of ferric oxides (ferrihydrite, goethite, and hematite): Applied Clay Science, v. 64, p. 38-43.

van Schaik, J. W. J., Persson, I., Kleja, D. B., and Gustafsson, J. P., 2008, EXAFS study on the reactions between iron and fulvic acid in acid aqueous solutions: Environmental Science and Technology, v. 42, p. 2367-2373.

Violier, E., Inglett, P. W., Hunter, K., Roychoudhury, A. N., and Van Cappellen, P., 2000, The ferrozine method revisited: Fe(II)/Fe(III) determination in natural waters: Applied Geochemistry, v. 15, p. 785-790.

Voelker, B., Morel, F., and Sulzberger, B., 1997, Iron redox cycling in surface waters: Effects of humic substances and light: Environmental Science and Technology, v. 31, p. 1004-1011.

Wojdyr, M., 2010, Fityk: A general-purpose peak fitting program. : Journal of Applied Crystallography, v. 43, p. 1126-1128.

Zhao, J., Huggins, F. E., Feng, Z., and Huffman, G. P., 1994, Ferrihydrite: Surface structure and its effects on phase transformation: Clays and Clay Minerals, v. 42, p. 737-746. 